TI 2012-062/3

Tinbergen Institute Discussion Paper

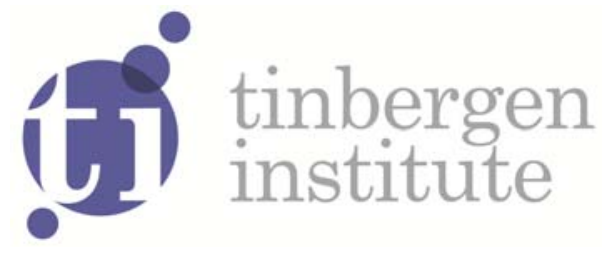

\title{
Why do Entrepreneurial Parents have Entrepreneurial Children?
}

Matthew Lindquist ${ }^{1}$

Joeri Sol2

Mirjam van Praag 2,3

1 SOFI Stockholm University, Sweden;

2 Amsterdam School of Economics, University of Amsterdam, the Netherlands;

3 Copenhagen Business School, and Tinbergen Institute, the Netherlands. 
Tinbergen Institute is the graduate school and research institute in economics of Erasmus University Rotterdam, the University of Amsterdam and VU University Amsterdam.

More TI discussion papers can be downloaded at http://www.tinbergen.nl

Tinbergen Institute has two locations:

Tinbergen Institute Amsterdam

Gustav Mahlerplein 117

1082 MS Amsterdam

The Netherlands

Tel.: +31(0)205251600

Tinbergen Institute Rotterdam

Burg. Oudlaan 50

3062 PA Rotterdam

The Netherlands

Tel.: +31(0)10 4088900

Fax: $+31(0) 104089031$

Duisenberg school of finance is a collaboration of the Dutch financial sector and universities, with the ambition to support innovative research and offer top quality academic education in core areas of finance.

DSF research papers can be downloaded at: http://www.dsf.nl/

Duisenberg school of finance

Gustav Mahlerplein 117

1082 MS Amsterdam

The Netherlands

Tel.: +31(0)20 5258579 


\title{
Why Do Entrepreneurial Parents Have Entrepreneurial Children? ${ }^{*}$
}

\author{
Accepted for publication in the Journal of Labor Economics
}

April, 2014

Matthew J. Lindquist

SOFI, Stockholm University

Matthew.Lindquist@sofi.su.se

\author{
Joeri Sol \\ Amsterdam School of Economics \\ University of Amsterdam \\ J.Sol@uva.nl \\ Mirjam Van Praag \\ Copenhagen Business School \\ Tinbergen Institute \\ Amsterdam School of Economics \\ University of Amsterdam \\ C.M.vanPraag@uva.nl
}

\begin{abstract}
Parental entrepreneurship is one of the strongest determinants of own entrepreneurship. We explore the origins of the intergenerational association in entrepreneurship using Swedish adoption data that allow us to quantify the relative importance of pre-birth and post-birth factors (nature and nurture). We also use comparable data on entrepreneurship for a large, representative sample of the Swedish population. We find that parental entrepreneurship increases the probability of children's entrepreneurship by about $60 \%$. For adoptees, both biological and adoptive parents make significant contributions to this association. These contributions, however, are quite different in size. Post-birth factors (adoptive parents) account for twice as much as pre-birth factors (biological parents) in our decomposition of the intergenerational association in entrepreneurship. We investigate several candidate explanations for this large post-birth factor and present suggestive evidence in favor of role modeling.
\end{abstract}

Keywords: adoption, entrepreneurship, self-employment, intergenerational mobility, occupational choice, role model.

JEL codes: J24, J62, L26.

\footnotetext{
* We thank David Cesarini, Nicos Nicolaou, Erik Plug, and seminar participants at ABEE (Amsterdam), ISEG (Technical University of Lisbon), IZA (Bonn), Linnaeus University, Norwegian Business School, IFN (Stockholm), and the Uddeville Conference on Innovation and Industrial Economics (University of Faro) for their useful comments. Matthew Lindquist gratefully acknowledges financial support from the Swedish Council for Working Life and Social Research (FAS).
} 


\section{Introduction}

Why do some people become entrepreneurs, but not others? The entrepreneurship literature asserts a number of factors that influence this choice. ${ }^{1}$ The most prominent among these factors is parental entrepreneurship. Having an entrepreneur for a parent increases the probability that a child ends up as an entrepreneur by a factor of 1.3 to 3.0 (Dunn and HoltzEakin 2000, Arum and Mueller 2004, Sørensen 2007, Colombier and Masclet 2008, Andersson and Hammarstedt 2010 and 2011).

While this stylized fact is widely accepted, there is no consensus concerning the origins of this intergenerational transfer of entrepreneurship. Thus far, none of the studies that explore various environmental explanations control for the transfer of genes from parent to child. This may bias their results given that recent twin studies find a large genetic component in the choice to become an entrepreneur (Nicolaou et al. 2008, Zhang et al. 2009, Nicolaou and Shane 2010, Nicolaou and Shane 2011, Koellinger et al. 2012). ${ }^{2}$ On the other hand, twin studies do not address the numerous environmental determinants of entrepreneurship posited in the literature.

We contribute to this literature by decomposing the intergenerational transmission of entrepreneurship into pre-birth factors (genes, pre- and peri-natal environment) and post-birth factors using Swedish adoption data that include information on entrepreneurship for all four parents of adopted children who were born in Sweden. This allows us to gauge the relative importance of nature and nurture in the reproduction of entrepreneurship from one generation

\footnotetext{
${ }^{1}$ Environmental factors include capital constraints (Blanchflower and Oswald 1998), peer effects (Nanda and Sørensen 2010), and regional influences (Reynolds, Storey, and Westhead 1994). Several heritable traits, such as risk aversion (Cesarini et al. 2009a), extraversion (Bouchard and Loehlin 2001), and overconfidence (Cesarini et al. 2009b) relate to the choice for entrepreneurship; see van Praag and Cramer (2001), Baron and Markman (2003), Koellinger et al. (2007), respectively for evidence. Other factors are discussed in Parker (2009) who also discusses different definitions used for entrepreneurship. In this paper we use entrepreneur and self-employed interchangeably. For the description of our identifying variable for entrepreneurship see Section 3.

${ }^{2}$ Genome-wide studies have, thus far, been unable to replicate these twins studies, probably due to the fact that they are still underpowered (i.e., they are trying to map a complex relationship with samples that are too small). See Koellinger et al. (2010) and Koellinger et al. (2012).
} 
to the next. We also run comparable exercises for a large, representative sample of nonadoptees.

We find that having an entrepreneur for a parent increases the probability that ownbirth children become entrepreneurs by $60 \%$. The size of this association is consistent with earlier studies. ${ }^{3}$ Our decomposition exercise with adopted children reveals that both biological and adoptive parents make significant contributions. However, the impact of post-birth factors (i.e., the influence of adoptive parents) is approximately twice as large as the impact of prebirth factors (i.e., the influence of biological parents). This difference is significant, and robust to several definitions of entrepreneurship. We find no evidence of a non-linear relationship.

We then examine several candidate explanations of this important post-birth effect. Fairlie and Robb (2007a) and Parker (2009) summarize the empirical evidence for and against different explanations of the intergenerational transfer of entrepreneurship that exists in the literature. They both argue that there is little evidence for two of the most common hypotheses: (i) the inheritance of the family business, and (ii) access to cheap capital provided by self-employed parents. There is mixed evidence for: (iii) acquisition of general business human capital due to the proximity of self-employed parents, (iv) industry- or firm-specific human capital formation, possibly including access to the business network of parents, and (v) correlated preferences between parents and their offspring, possibly enhanced by role modeling (with the understanding that preferences may have an heritable component). ${ }^{4}$

There is clear consensus that inheritance (or transfers of ownership or gifts) does not explain intergenerational entrepreneurship (Parker 2009). US evidence produces estimates that $5.6 \%$ of the businesses are acquired by inheritance $(1.6 \%)$ or gifts $(4 \%)$. Canadian and Danish evidence produces similar numbers of 5.5\% (Aldrich, Renzulli, and Langton 1998)

\footnotetext{
${ }^{3}$ For Sweden, see Andersson and Hammarstedt (2010, 2011).

${ }^{4}$ See, e.g., Cesarini et al. (2009a, 2009b) and Dohmen et al. (2012).
} 
and $8 \%$ (Sørensen 2007), respectively. In our data, we can use the same indirect measure as Sørensen (2007) to confirm that inheritance does not explain much of the intergenerational association in entrepreneurship.

Dunn and Holtz-Eakin (2000) show that the assets of self-employed parents have a positive and significant effect on the transition into entrepreneurship, however the marginal effects are almost negligible. In Sørensen (2007), parental wealth does not explain the transfer of entrepreneurship. Moreover, less than $8 \%$ of the business owners borrow capital from family (Fairlie and Robb, 2007a and Aldrich et al., 1998). In our analysis, neither parental income nor parental wealth explain the intergenerational transfer of entrepreneurship.

If it is easier for children of entrepreneurs to obtain 'general business' or managerial human capital, entrepreneurship might be a more promising career path and thus cause a correlation across generations not only of the probability of entrepreneurship but also of performance. Fairlie and Robb (2007a) find that having self-employed parents increases profits and sales, and lowers closure, but only when the entrepreneur has work experience in the family business. Sørensen (2007) and Roberts (1991) find no evidence that the children of self-employed perform better as entrepreneurs. In our paper, the intergenerational transfer of entrepreneurship remains similar in magnitude when we use stricter definitions for entrepreneurship that limit the set of entrepreneurs and/or entrepreneurial parents to the ones that are relatively successful (in terms of incorporation, survival and/or income). Thus, our findings do not support the hypothesis that entrepreneurial parents who perform better have a higher rate of intergenerational transmission, or that the association is stronger for enterprising children who are more successful.

Evidence in favor of the hypothesis that children of entrepreneurs have more opportunity to acquire industry- or firm-specific human capital, and may benefit from their parents' networks is less thin. Second generation entrepreneurs are two to three times more 
likely to work in the same occupation as their fathers (Corak and Piraino 2011, Dunn and Holtz-Eakin 2000, and Laband and Lentz 1983). Sørensen (2007) also finds that the children of entrepreneurs choose the same industry as their parents more often. We address the industry-specific human capital explanation by including industry dummies in our intergenerational transfer model. The inclusion of these dummies leads to a drop of our estimates of (at most) 10\%, suggesting that the acquisition of industry-specific human capital can only explain a small part of the intergenerational association in entrepreneurship.

The fifth explanation put forth in Parker's (2009) overview is that entrepreneurial parents may transmit the taste for entrepreneurship through role modeling. This may be as subtle as increasing the child's awareness of entrepreneurship as a career option (Carroll and Mosakowski 1987), or shaping the child's values, such as a taste for autonomy. Sørensen (2007) shows a sizeable transmission of entrepreneurship for children who have only been exposed to parental entrepreneurship before the age of 16 .

We address role modeling by exploring differential parent-child transmissions of entrepreneurship among the same sex. A stronger same sex transmission of entrepreneurship suggests the presence of role modeling; based on role model identification theory, role models are more often of the same gender (Ruef et al. 2003). More generally, homophily is prevalent in many relationships; that is, individuals have a tendency to bond easier with similar others (McPherson et al., 2001). We show that the transmission of entrepreneurship from mothers to daughters is significantly stronger than that from fathers to daughters, and for sons the effect of entrepreneurial fathers is significantly stronger than the effect of entrepreneurial mothers. ${ }^{5}$

Whereas none of the previous studies could control for a genetic transfer of entrepreneurship (and its correlates), our adoption study addresses to what extent the mechanisms above are driving a pure "nurture" effect, over and above the genetic transfer of

\footnotetext{
${ }^{5}$ These findings are also consistent with the idea that parents may invest more in same-sex children (Thomas 1994). We distinguish between these two explanations in Section 6.1.
} 
entrepreneurship. The adoption methodology (and subsequent sensitivity analyses) we use was pioneered by Björklund et al. (2006) who studied the intergenerational transmission of income and education. Other recent papers using the Björklund et al. (2006) methodology and similar data include Hjalmarsson and Lindquist (forthcoming) who study intergenerational correlations in crime and Cesarini et al. (2012) who study voting behavior.

We use the Björklund et al. (2006) research design to address a new question. Our findings speak directly to the debate concerning the etiology of entrepreneurship (in general) and to the determinants of the intergenerational correlation in entrepreneurship (in particular). We also go further than previous adoption studies by focusing more attention on identifying and understanding the relative importance of different, hypothesized post-birth mechanisms.

The entrepreneurship literature that we are addressing has grown considerably over the last decade. This is partly motivated by the effects of entrepreneurship on job creation and innovation (see, for example, Acs 1999, Birch 1979, and Van Praag and Versloot 2009, and Shane 2009 who provides a critical note) and to the development of public policy at various levels in order to promote entrepreneurship (e.g., Klapper, Laeven and Rajan, 2006; Storey, 2006). We argue that an increased understanding of the origins of the transmissions of entrepreneurship may help to guide public policies and entrepreneurship education. Our results suggest that there is scope to sway people in the direction of entrepreneurship, either by public policies or within the education system, as post-birth factors play an important role in determining this occupational choice. In addition, our findings suggest that a further exploration of the effects and determinant of role models for entrepreneurship may be fruitful; Bosma et al. (2012) take a first step in this direction.

Our paper proceeds as follows: We present our empirical methodology and discuss threats to identification in Section 2. In Section 3, we provide a description of the Swedish adoption procedure, our data set, and a set of descriptive statistics. Our baseline results of the 
intergenerational transmission of entrepreneurship and decomposition exercise are presented in Section 4, which is followed by a sensitivity analysis in Section 5. Section 6 examines the plausibility of several nurture explanations for the post-birth transmission of entrepreneurship. Section 7 concludes.

\section{Empirical Methodology}

\subsection{Regression Models}

We begin by regressing our measure of entrepreneurship for a non-adopted child born into family $i$ on our measure of entrepreneurship for the parents, in order to obtain an estimate of the intergenerational association in entrepreneurship, $\beta_{1}$ :

$$
E_{i}^{b c}=\beta_{0}+\beta_{1} E_{i}^{b p}+\nu_{i}^{b c}
$$

Previous research has found strong intergenerational associations in entrepreneurship. Thus, we expect $\beta_{1}$ to be significantly positive.

The key question addressed in this paper is why we find an intergenerational association in entrepreneurship? Potential mechanisms can be placed into two broad categories that we label pre-birth and post-birth factors. Pre-birth factors include genetic influences and intra-uterine environment. Post-birth factors include parental role modeling, direct transfers of (general or specific) human capital, financial capital, or inheritance of the family business.

The Björklund et al. (2006) methodology makes use of adoption data with information on all four parents of adopted children in order to estimate these pre-birth and post-birth factors directly. With these estimates, we can assess the relative importance of pre- and postbirth factors for generating the observed intergenerational association in entrepreneurship, $\beta_{1}$.

Using our adoption data, we estimate the following linear regression model: 


$$
E_{j}^{a c}=\alpha_{0}+\alpha_{1} E_{i}^{b p}+\alpha_{2} E_{j}^{a p}+v_{j}^{a c} .
$$

We regress our measure of entrepreneurship for a child born into family $i$ but then adopted by family $j$ on the entrepreneurship status of all four parents. Under certain assumptions (spelled out in Section 2.2), the coefficient on biological parents' entrepreneurship, $\alpha_{1}$, is a consistent estimate of pre-birth factors and the coefficient on adoptive parents' entrepreneurship, $\alpha_{2}$, is a consistent estimate of post-birth factors. An additional set of assumptions is required to generalize our estimates of the relative importance of pre- and post- birth effects beyond our sample of adopted children (these are also spelled out in Section 2.2).

We estimate equations (1) and (2) using OLS. The terms $v_{i}^{b c}$ and $v_{j}^{a c}$ in equations (1) and (2) are the OLS regression error terms. Since entrepreneurial activities are bound to vary at different stages of the lifecycle, and since our data are partially censored by age (more on this in Section 3), we include year of birth dummies for children and each parent in our regressions. We also include a county of residence dummy for where the child lived in 1965 (when young) to control for variations in business activities across geographic areas and a gender dummy for the child to account for gender differences in entrepreneurship.

\subsection{Identifying Assumptions}

In order to interpret $\alpha_{1}$ and $\alpha_{2}$ as pre- and post-birth factors, we have to make two assumptions. First, we assume that adoptees are randomly assigned to families or that they are assigned to families according to rules that one can control for. If adoption agencies use information about the biological parents to match children to adoptive parents, then the preand post-birth characteristics will be correlated, yielding biased coefficients. Second, we assume that children move immediately to their adopting family. If this assumption is violated, 
then it is possible that the estimated pre-birth factors are too high since they capture some of the post-birth environment; in contrast, the estimated post-birth factors will be too low.

To compare $\beta_{1}$ with $\left(\alpha_{1}+\alpha_{2}\right)$, we must make three additional assumptions. First, biological and adopted children are drawn from the same distribution of children. That is, adopted away children have the same pre-birth characteristics as own-birth children. Second, biological and adopting parents are drawn from the same distribution of parents. That is, adoptive parents provide the same post-birth environment as own-birth parents. Third, parents treat adopted and own-birth children similarly.

We have also assumed that pre-birth and post-birth factors enter the production function of the child's entrepreneurship choice linearly and additively. However, geneenvironment interactions are a widely discussed issue in the behavioral genetics literature. In case of significant gene-environment interactions our linear model will be misspecified.

All of the assumptions above may be readily violated. In Section 5, we discuss the extent to which these assumptions are satisfied and the potential sensitivity of the baseline results to violations of these assumptions.

\section{Institutions and Data}

\subsection{Adoptions in Sweden}

In this Section, we present a brief description of the Swedish adoption process. ${ }^{6} \mathrm{We}$ focus on adoption procedures that were in place during the 1940 's, ' 50 's, and ' 60 's, since this is the system that our cohorts of children were born into. All adoptions in Sweden are made through the court system. Private adoptions were (and still are) illegal. Courts acted in conjunction with the local social welfare authorities that, in turn, had the primary responsibility for

\footnotetext{
${ }^{6}$ Our description is based primarily on three sources: Barnhuset (1955), Bohman (1970) and Nordlöf (2001) and closely follows the presentation in Hjalmarsson and Lindquist (forthcoming).
} 
investigating the suitability of prospective adopting parents and for safeguarding the interests of the children.

Adoption of small children was done anonymously. ${ }^{7}$ However, the identities of the biological parents (when known) and adopting parents were recorded in the court decision and were kept in the census records as well. Due to the formal nature of the adoption process, the biological mother is typically known to the social authorities. Also, one of the first jobs of the social worker assigned to the case was to attempt to identify the biological father. This is how we can link adopted children to their biological and adopting parents.

There were very few explicit legal requirements concerning who was eligible to adopt a child. Adopting parents had to be at least 25 years old and free of tuberculosis or sexually transmitted diseases. Adoption by relatives was allowed, but very rare (Nordlöf 2001). Informally, the local social authorities used the following rules and recommendations. The adopting family must have adequate housing and the adopting father should have a steady income. The couple should be legally married and the adopting mother should be able to stay at home, at least while the child was small. The adopting couple should not have any biological children and it should be highly unlikely that they could in the future. The adopting parents should not be too old. In practice, as we shall see in the data in the next Section, adoptive parents tend to be somewhat positively selected in terms of education and income, but not to the same degree that we see today in the modern adoption process.

Children were not placed into their new families at random. Whenever possible, the social authorities wanted to match children based on their biological parents' intellectual

\footnotetext{
${ }^{7}$ Until 1959, adoptions in Sweden were so-called "weak" adoptions. That is, not all ties between the biological parents and their adopted away child were permanently cut. Biological parents still had a legal responsibility to support the child economically if the new, adopting family could not. Furthermore, the adopted child would still inherit from his/her biological parents. The legalities concerning weak adoptions, however, did not lead to any direct contact between the adopted away child and his/her biological parents. Starting in 1959, all legal ties between biological parents and their adopted away children were permanently cut. From then on, only "strong" adoptions were allowed. In 1971, all weak (pre-1959) adoptions were turned into strong adoptions.
} 
capabilities, particular talents and physical appearance. Their hope was that parents would "recognize" themselves in their adopted child and that the child would feel a sense of belonging. However, after conditioning on a set of observable characteristics (age, marital status, income and education), the evaluation literature (reviewed in Bohman 1970) finds no evidence that the social authorities were able to predict which parents would provide the needed emotional environment. It was hard to say ex ante who would grow into their role and become a good parent and who would not. The evaluation literature also argues that it is actually these types of less well defined variables (emotional environment, parenting skills, marital harmony, etc.) that are correlated with adopted children's maladjustment, school performance and anti-social behavior; adoptive parents income, education, etc. are not (Bohman 1970). In this sense, one can argue that many important "environmental" factors are conditionally randomly assigned to children. ${ }^{8}$

In general, children put up for adoption were born to unwed mothers, had lower birth weights and poorer health outcomes (Bohman 1970). There were four initial placement possibilities for newborn children. Babies were either placed in a special nursery, in a home for unwed mothers, in temporary foster care, or directly in the home of the adopting family. Prior to 1970 , children with visible handicaps, severe health problems or whose parents suffered from severe cases of mental illness, alcoholism or criminality were not always put up for adoption. In many instances, these children were either put into foster care or institutional care. This means that those children who were put up for adoption were a positively selected group from a somewhat negatively selected pool of children (in terms of birth weight, health outcomes and parental histories). The sample of adoptees studied by Bohman (1970), for

\footnotetext{
${ }^{8}$ One example of this is that prospective parents were interviewed on health issues and marital harmony. The explicit goal of these interviews was to place children in stable homes with lower chances of dissolution due to death or divorce. Despite these efforts, the sample studied by Bohman (1970) experienced the same rate of parental death and divorce as the population at large.
} 
example, had the same average birth weight and health outcomes (at ages $10-11$ ) as their non-adopted peers in school.

Lastly, the relative importance of the four types of placement changed over time. In Stockholm County, for example, the share of children that were permanently placed in their adoptive homes before age one rose between 1940 and 1973 from 63 to 83 percent (Nordlöf 2001). The share of children arriving at their permanent adopting home between ages one and two fell from 16 to 11 percent and ages two and three from 10 to 3 percent (Nordlöf 2001). Thus, 90 - 97 percent of all children were permanently placed before age three during this time period. Using nationwide data drawn from the same sources as our own data, Björklund et al. (2006) report that 80 percent of adoptees born in the 1960s were living with their new families before age one. Using the census data from 1960, 1965 and 1970, our analysis shows a similar percentage of $75-80 \%$. In sum, a non-trivial share of our sample of adopted children has been placed in their adoptive families after the age of one. ${ }^{9}$

\subsection{Data and Descriptive Statistics}

The data were assembled as follows. Statistics Sweden began by drawing a 25 percent random sample from Sweden's Multigenerational Register, which includes all persons born from 1932 onwards who have lived in Sweden at any time since 1961. Statistics Sweden also identified all individuals adopted by at least one parent in Sweden. Mothers and fathers, brothers and sisters, and children of each adopted individual as well as each index person in the 25 percent random sample were matched onto the sample. Register data concerning entrepreneurship (defined as self-employed who derive the majority of their taxable income

\footnotetext{
${ }^{9}$ The actual placement guidelines in 1945 suggested that a child should be adopted at age one after a six months trial period in the home. In 1968, the guidelines suggested that the baby should be placed with its new family at age $3-6$ months and be adopted 3-4 months later. When these guidelines were not followed, the tendency was to place the baby earlier (rather than later) with the adopting family (Nordlöf 2001). Note also that some adoptees may be misclassified as "late" adoptees, because they were first placed in a foster home and later adopted by their foster parents (Bohman 1970). Also, children were most likely registered at their biological mothers address until the official adoption process was complete.
} 
from a business that they own in full or in part), income, education, industry, place of residence, year of birth and death, and year of immigration and/or emigration were then matched to this sample using the unique identification number that each Swedish resident is assigned.

Since adoption in Sweden is a centralized legal procedure, the registry identifies whether a person has been adopted and identifies the adoptive mothers and fathers. For those adopted children who were born in Sweden and included in our baseline sample, we can also identify 85 percent of their biological mothers and 43 percent of their biological fathers. ${ }^{10}$ Knowing the identities of the biological parents of adopted children is quite unique to these Swedish data and is the key to our empirical strategy. ${ }^{11}$

We use this data set to create two samples; an adoptive sample and a non-adoptive sample. Table 1 lists the sample restrictions that we impose and the corresponding impacts on sample sizes. Our raw data set contains 7,408,044 non-adopted individuals and 143,490 individuals adopted by at least one parent. Restricting our adoption sample to those adopted by both parents reduces it to 91,447 individuals. We restrict our non-adoption sample to the 2,448,405 index persons (i.e., those in the original 25 percent random sample).

For both the adoption and non-adoption samples, we impose the following additional restrictions. Since we only have information on the biological parents of adopted children who were born in Sweden, we eliminate all children in both samples who were born abroad. We also omit all children with at least one parent born before 1920. These individuals are most likely too old to have a chance to show up in our data on entrepreneurship, which start in 1985. Children who died or emigrated from Sweden before 1985 are dropped from the sample, as they cannot show up in our data on entrepreneurship. Likewise, we omit any child who had

\footnotetext{
${ }^{10}$ In Section 5, we address the issue of missing fathers.

${ }^{11}$ The only other (non-Swedish) data set that we are aware of that has information on all four parents is a new, Taiwanese data set. Tsou et al. (2012) use this data to study the intergenerational transmission of education in Taiwan.
} 
at least one parent (biological or adoptive) die or emigrate from Sweden before 1985. Together, these sample restrictions yield a non-adoption sample of 1,437,623 individuals and an adoption sample of 17,639 individuals.

We also eliminate individuals born in 1970 or later. We choose this year as our cutoff because (i) the birth control pill was approved in 1965 and (ii) legal abortions were gradually introduced in Sweden from 1965 to 1975. As a result of these medical and legal changes, the number of Sweden born adoptees fell dramatically and the biological parents of adopted away children became more negatively selected over time. Lastly, we drop all children for which we cannot identify both biological parents. This leaves us with 412,183 non-adopted children and 3,941 adopted children in our baseline sample. Among the adoptees, we have 2,149 sons and 1,792 daughters.

As mentioned above, we have access to data concerning entrepreneurship, income, education, and industry. For the years 1985 to 2008, we know if the individual received the majority of his or her taxable labor income from an unincorporated enterprise. This enterprise could be owned and operated solely by him- or herself or together with others. Thus, information on self-employment status is known for these years. For the years 1993 to 2008, we also know if a person received the majority of his or her taxable labor income from an incorporated enterprise owned in part or in full by him- or herself. We use these two pieces of information (self-employment and incorporated) in order to categorize people as entrepreneurs (more on this shortly). ${ }^{12} 13$

\footnotetext{
${ }^{12}$ The fact that we do not have information before 1993 on those working in their own incorporated enterprise, implies that we are underestimating the true extent of entrepreneurship for the years 1985-1992. For the years 1993-2001, roughly 2 percent of the sample is employed in his or her own incorporated enterprise each year. Thus, one might assume that it is approximately true for the years 1985-1992 as well.

${ }^{13}$ Note that Farmers are included in Statistics Sweden's definition of entrepreneurs, since farms are typically run as companies (either incorporated or unincorporated). Statistics Sweden changed their routines for collecting information on entrepreneurship in 2004. At the same time, they also changed the definition so that it now includes those who are self-employed in enterprises that report zero profits or even losses. This produces a discrete upwards jump in the number of self-employed in our data. The share of entrepreneurs in our sample rises from $4.2 \%$ in 2003 to $4.8 \%$ in 2004 . This jump is mainly due to an increase of self-employed working in
} 
We use the above information to create our baseline measure of "entrepreneurship". Our primary outcome variable, Entrepreneur, is an extensive margin variable equal to one if the individual was either self-employed in an unincorporated firm or owner of an incorporated firm at least once between the years 1985 and 2008, and zero otherwise. Recall that individuals are classified as entrepreneurs if their largest source of labor income is derived from a company (either incorporated or unincorporated) that they own in full or in part. We also create a second, more narrow definition of entrepreneur, Incorporated, which is equal to one if an individual derived the majority of his/her taxable income from an incorporated enterprise that he/she was at least part owner of at least once between the years 1993-2008, and zero otherwise.

We have tax register data for the years 1968-2007 for each person in our sample. We use these data to create two measures of income. The first variable, Income, is equal to the log of average income, which is income averaged across all available income years for each person. There are very few zeros or missing in our income tax data. Those zeros that do exist are treated as missing and, hence, not included in average income. The income definition that we use is pre-tax net total factor income, which is the broadest definition of income available to us. We also create a second income variable labeled, Entrepreneurial Income, which is equal to the log of average income using income only from those years an individual is labeled an Entrepreneur.

Education is measured in 7 levels: (i) less than 9 years of grade school, (ii) completed 9 years of grade school, (iii) at most 2 years of high school, (iv) 2 to 3 years of high school, (v) less than 3 years of college, (vi) at least 3 years of college, and (vii) graduate studies. ${ }^{14}$ still derive the majority of their labor income from this enterprise to be classified as an entrepreneur.

${ }^{14}$ Most of this information has been taken from Sweden's national education register for the year 1990. If education was missing in this primary source, then secondary sources were searched. This was done in the following order: the national education registers for 1993, 1996 and 1999 and, finally, the 1970 Census. 
Education levels are translated into the variable Years of Schooling as follows; 7, 9, 11, 12, 14, 15.5, and 19 years. We also have information concerning the Industry in which people work. This is comprised of 42 two-digit SNI industry codes.

Descriptive statistics for our baseline sample are shown in Table 2. Part a shows means and standard deviations, whereas part b shows correlations of interest. When focusing on the children, the values of our measures of entrepreneurship are quite similar for own-birth and adopted children. The share of both types of daughters labeled Entrepreneur is 14 percent, and also the share of Incorporated is similar (4 percent). For sons, the share of Entrepreneurs is 25 and 23 percent for own-birth and adopted sons, respectively. The difference in terms of Incorporated are somewhat larger (in relative terms). The share of Incorporated is 11 percent for own-birth sons and 8 percent for adopted sons. Adopted children have (on average) slightly lower levels of income and education than own-birth children. They are also roughly 2.5 years younger than own-birth children in our sample.

Adoptive parents and parents with own-birth children have nearly identical values for Entrepreneur and Incorporated. The variables for birth parents who put a child up for adoption, on the other hand, are much lower. The share of Entrepreneurs among birth mothers who adopt away their child is 10 percent, while for adoptive mothers and mothers with own-birth children the share is 15 percent. The share of Incorporated, however, is 2 percent in all three groups of mothers. The share of Entrepreneurs among birth fathers who adopt away their child is 20 percent, while for adoptive fathers and fathers with own-birth children the share is 27 and 26 percent, respectively. The share of Incorporated, however, is roughly the same in all three groups of fathers. It lies between 4 and 5 percent. Note also that the adoptive parents are several years older (on average) than the parents with own-birth children, who are, in turn, several years older than the birth parents who adopt away their 
child. Adoptive fathers have a full year of schooling more than birth fathers of adopted children and their incomes are also higher.

Taken together, these statistics indicate that the degree of entrepreneurship is somewhat lower among the birth parents of adopted away children. These children are adopted by parents who display the same degree of entrepreneurship as other parents. They also highlight the importance of controlling for year of birth in the empirical specifications, as adopted children tend to be younger than own-birth children and adoptive parents tend to be older than biological parents. We also see some evidence in our data that the birth parents of adopted children are slightly negatively selected in terms of their average education and income levels. In contrast, adoptive parents (in particular fathers) are positively selected in terms of education and income.

Part $\mathrm{b}$ of Table 2 shows that the likelihood of being an Entrepreneur is higher for children with parents who were entrepreneurs. For own-birth children the correlation between their own Entrepreneur status and their parents is between 11 and 12 percent and similar for both parents. For adopted children, the correlation between parental and own entrepreneurship is larger for adoptive parents than for the biological parents and, again, not much different for fathers and mothers.

Part $b$ of Table 2 further shows that the entrepreneurship status of fathers and mothers is highly correlated, around 40 percent. This may be due to assortative mating or setting up firms jointly. For the biological parents of adopted children this correlation is much lower, but significant $(6.5 \%)$, consistent with the fact that these parents have often not long been together. Finally, it is also notable that the entrepreneur status of biological and adoptive parents is unrelated. Children of entrepreneurial parents are not more or less likely to be placed with adoptive parents who are also entrepreneurs. 


\section{Results: The relative importance of nature and nurture}

\subsection{Baseline results}

Table 3 presents the results of the baseline regressions for the sample of own-birth children in the top panel and for the sample of adopted children in the middle panel. The dependent variable in all equations is a dummy that is one for "children" who have been or are entrepreneurs and zero otherwise (Entrepreneur). The explanatory variable of interest in Column (1) is a dummy (defined likewise) that indicates whether either parent is or has been an entrepreneur. In column (2) only the fathers' entrepreneurial experience is considered, whereas column (3) does so for the mothers. Column (4) includes all parents in one regression. Besides the coefficients that indicate the effect of these variables on the child's likelihood of entrepreneurship in terms of percentage points, the table also shows the effect in percentages. All regressions include year of birth dummies for children and parents, and gender and county of residence (in or around 1965) dummies for the child. The coefficients of these control variables are not reported for ease of presentation. The bottom panel provides F-tests on the equality of pre- and post-birth factors and a comparison of the estimates between the two samples.

First, consider the top panel, where we show the intergenerational transfer of entrepreneurship for own-birth children. Taken as a whole, the likelihood to experience a spell of entrepreneurship significantly increases by having an entrepreneur for a parent. Parental entrepreneurship raises the probability that the offspring will experience entrepreneurship by 11.6 percentage points (or $61 \%$, see column (1)). In addition, the results indicate that the entrepreneurial experience of fathers and mothers is equally important. The effects of parental entrepreneurship (in columns (2) and (3)) when fathers and mothers are included separately are similar in magnitude to column (1), but decrease when both are included simultaneously (column (4)). The drop in the coefficients indicates that the 
entrepreneurship likelihood of the partners is correlated positively (see Table 2b). Still, either parents' experience with entrepreneurship significantly increases the probability that a child ends up as an entrepreneur by roughly $45 \%$. Thus, the child is almost twice as likely to become an entrepreneur when both parents have experienced entrepreneurship.

Next, in the middle panel, we decompose the intergenerational transmission estimates in pre- and post-birth factors based on the sample of adopted children. The entrepreneurial experience of both biological parents and adoptive parents significantly raise the probability that an adoptee will be observed as an entrepreneur. Biological parents' entrepreneurship increases the offspring's tendency to become entrepreneurs by approximately $20 \%$. The estimates are consistent across regressions, and significant at the 5\% level except for the biological mothers' experience. ${ }^{15}$ The impact of biological fathers and mothers is almost identical in size, which makes it unlikely that the in utero environment influences this occupational choice. The estimates for the effect of adoptive parents' entrepreneurship indicate that post-birth factors contribute about twice as much to the intergenerational transfer of entrepreneurship as pre-birth factors do. A history with entrepreneurship among adoptive parent raises the likelihood that an adoptee will be observed as an entrepreneur by $45 \%{ }^{16}$ The F-tests in the bottom panel show that the effect of the adoptive parent is significantly larger than the effect of the biological parent (for column 1 the $p$-value is 0.026 ).

Finally, the bottom panel of Table 3 presents the sum of biological and adoptive parent coefficients and the confidence intervals of these sums. The sum of the estimated pre-birth and post-birth factors for adoptees is remarkably similar to the intergenerational association

\footnotetext{
${ }^{15}$ It may well be that the difference in significance is due to the lower occurrence of entrepreneurship among mothers than fathers (see Table 2). In section 5.2 we show indeed that the effect of biological mothers turns significant once we extend our sample size to those adoptees for whom the information on the biological fathers is missing.

${ }^{16}$ Again, we see a drop in the coefficients when both adoptive fathers and mothers are included. This drop is not observed for the biological parents of adoptees: for them the entrepreneurship outcome of the father and the mother is much less strongly correlated (see Table $2 b$ ).
} 
for own-birth children. That is, we find no evidence that being adopted has an impact on the intergenerational transfer of entrepreneurship. ${ }^{17}$

In summary, Table 3 gives us the following insights: First, there is a significant parentchild transmission of entrepreneurship. The likelihood that someone is observed as an entrepreneur increases by about $45 \%$ to $65 \%$ if the parent is or was an entrepreneur. This finding is consistent with earlier studies; e.g., Sørensen (2007) found an association of similar size in Denmark. Second, this transmission is the same for entrepreneurial fathers and mothers. Third, when considering adopted children, we see that both biological and adoptive parents have a significant contribution. Approximately one third of the intergenerational association in entrepreneurship is accounted for by pre-birth factors, whereas two-third of the association can be attributed to post-birth factors. The difference between the estimated size of pre-birth and post-birth factors is significant. Fourth, being adopted has no impact on the intergenerational transfer of entrepreneurship; that is, the parent-child transmission for nonadoptees falls within the interval of the summed effect of the biological parents and adoptive parents for adopted children.

\subsection{Stricter definitions of entrepreneurship}

The definition of entrepreneurship used in Table 3 implies that observations are counted as entrepreneurs as soon as they either have ever been registered as self-employed or as owner of an incorporated business; no matter how long, serious or successful their spell of entrepreneurship was. Table 4 reports the intergenerational transmission estimates for various

\footnotetext{
${ }^{17}$ As a robustness check we test whether being adopted has an impact on the transfer of entrepreneurship in the pooled sample of own-birth children and adoptees. We regress entrepreneurship of children on entrepreneurship of their pre-birth and post-birth parents (which only differ for adoptees) and a cross-term of entrepreneurship by either post-birth parent with an indicator for being adopted. The coefficient of this cross-term should be zero when the total effect of parental entrepreneurship is the same for adoptees and own-birth children. The results mimic those in Table 3 column (1). The estimates of the effects of pre-birth and post-birth parents are 0.040 and 0.076 , respectively. The estimate for the cross-term is indeed insignificant and the size $(0.005)$ is identical to the difference between the estimates in the top and bottom panel of column (1) in Table 3.
} 
(stricter) definitions of entrepreneurship, using similar regressions as in column (1) of Table 3. In Table 4 Part A the stricter definition of entrepreneurship is applied only to the children. In Table 4 Part B the stricter definition is also applied to the definition of parental entrepreneurship.

The first column of Table 4 is a copy of the first column of Table 3 and serves as a benchmark. The dependent variable in column (2), "Entrepreneur_1", is equal to one whenever someone has been the owner of an incorporated firm and zero otherwise. This definition leaves us with $40 \%$ of the entrepreneurs in the base sample. "Entrepreneur_2" in column (3) restricts the original definition in terms of duration and equals one if someone has been an entrepreneur for at least three years and is zero otherwise, thereby cutting off 30 percent from the original sample of entrepreneurs. For "Entrepreneur_3" in column (4) we cut off the same percentage, i.e. the bottom 30 percent, but in this case by using the entrepreneurial (log) income distribution. The dependent variable in column (5) combines the definitions used in columns (3) and (4). It is one for entrepreneurs who have been in business for at least three years and earned incomes belonging to the upper $70 \%$ of the income distribution. This is the case for half of the entrepreneurs used in Table $3 .^{18}$

Table 4 shows that entrepreneurial parents raise the probability of a child to become an entrepreneur by approximately $45 \%$ to $65 \%$, also when restricting the sample of entrepreneurs to only those who satisfy stricter definitions of entrepreneurship. ${ }^{19}$ Both when applying the stricter definition of entrepreneurship to the children only (Part A) and when applying it symmetrically to both the child and their parents, we find estimates resonating the results in

\footnotetext{
${ }^{18}$ If the duration and income distributions were independent, this would lead to a sample of 49 percent of the original $(70 \% \times 70 \%)$. However, due to a positive correlation $(0.16)$ the percentage is 52.

${ }^{19}$ Please note that the estimated effects in percentage points are lower for stricter definitions due to their lower average levels in the sample.
} 
Table $3 .^{20}$ When we consider the sample of adopted children, we find a larger effect of the adoptive parents than of the biological parents for all definitions of entrepreneurship. The ratio of the pre- and post-birth factors' remains approximately one third (biological) versus two thirds (adoptive), and is significantly different except in column (4). Moreover, as we saw in Table 3, the sum of the estimated impacts of the biological and adoptive parents estimated using our sample of adoptees is of similar magnitude as the effect of parental entrepreneurship on their children's entrepreneurship for non-adoptees. In short, our conclusion from Table 3 remain largely unchanged when using stricter definitions of entrepreneurship, irrespective of whether we use them for the children only (Part A) or symmetrically (Part B).

A comparison of Table 3 and Table 4 may also lead to the somewhat deeper discussion of what exactly is transmitted by entrepreneurial parents. Does the intergenerational transfer of entrepreneurship stem from a transmission of preferences or from talents and advantageous circumstances? In the case of preferences, one would expect that the estimated effects of parental transmissions do not increase when using more success-related definitions of entrepreneurship. However, in the second case, if talents and performance enhancing circumstances play a role, one would expect that the parental transmission coefficients would become stronger when using stricter definitions. Our findings suggest that the transmission of tastes and preferences play a larger role than performance enhancing factors. $^{21} 22$ This is especially true for pre-birth factors. The transmission of entrepreneurship

\footnotetext{
${ }^{20}$ One notable exception are the results for 'entrepreneur_1', incorporated entrepreneurship, where the parental transmission is more than three times as large when the stricter definition of entrepreneurship is also applied to parents. It seems to manifest itself through post-birth factors only.

${ }^{21}$ An additional 'back of the envelope' analysis, similar to Table 4 part A, confirms the idea that parental entrepreneurship is unrelated to entrepreneurship performance. For the entrepreneurs in the sample we have estimated three different performance equations, separately for own-birth and adopted children. We use Entrepreneur_1 (i.e., incorporation), 'Years entrepreneur' (continuous), and 'Entrepreneurial income' (continuous), as the dependent variables, respectively. Parental entrepreneurship does not affect the likelihood of incorporation, nor entrepreneurial income significantly. It does have a positive effect on 'Years entrepreneur'. When focusing on the sample of adoptees who are entrepreneurs, we see that biological parents play no significant role at all, whereas the adoptive parents affect 'Years Entrepreneur' but not income or incorporation. The results from these estimations are available upon request.
} 
via biological parents to adoptees seems to become weaker when using stricter definitions of entrepreneurship.

In summary, Table 4 indicates that the results in Table 3 carry over when using stricter definitions of entrepreneurship. Thus, our main result holds, regardless of the definition of 'who is an entrepreneur', which is much debated in the entrepreneurship literature (e.g., Parker, 2009). Moreover, if anything, the mechanism underlying the transmission of entrepreneurship seems rather related to tastes and preferences than to ability and performance. Some caution is warranted as the estimates in Table 4 are less precise due to the lower base percentage of entrepreneurs when using stricter definitions.

\section{Internal and External Validity}

The Björklund et al. (2006) "four parent" adoption methodology relies on a number of assumptions for its internal and external validity. Below, we implement a series of sensitivity analyses first outline in their original paper (Björklund et al. 2006) aimed at testing each of these underlying assumptions.

\subsection{Internal validity}

In this section, we address the validity of the underlying assumptions that insure the internal validity of our baseline results and test how sensitive these results are to departures from these assumptions. We run sensitivity analyses for four possible problems: (i) non-random assignment of adoptees to their adoptive parents, (ii) age at adoption, (iii) non-linearities, and (iv) reverse causality. The results are summarized in the following Subsections and in Table 5.

\footnotetext{
${ }^{22}$ Stretching this result a bit would mean that parental entrepreneurship could be used as an instrument for entrepreneurial intentions or choices among offspring while being unrelated to ability as an entrepreneur.
} 


\subsubsection{Nonrandom Assignment}

In case nonrandom placement of children to adoptive families occurs, our estimates of the decomposition of the pre- and post-birth factors might become biased, as we may pick up post-birth effects in our pre-birth estimates, and vice versa. Fortunately, by means of the detailed information on the biological parents of adoptees we can test the sensitivity of our results to the violation of this assumption (albeit only based on observable characteristics). Nonrandom placement with respect to entrepreneurship status does not seem to be an issue, as the biological and adoptive parents' entrepreneurship status are uncorrelated, even after controlling for other observable characteristics. ${ }^{23}$ We further check the validity of this suggestion by assessing to what extent our baseline results (row (1) of Table 5) for the adoptive parents change upon the exclusion of the biological parents' entrepreneurship status (row (2) of Table 5). We perform the same test on the estimates of the coefficients of the biological parents' entrepreneurship status by excluding the adoptive parents' entrepreneurship status controls from the regression (row (3) of Table 5). The resulting coefficients (in row (2) and (3)) are very similar to the corresponding estimates of the baseline equation (row (1)).

Finally, from Bjorklund et al. (2006), we know that the correlation between adoptive and biological parents is not zero when considering education level or income. Therefore, we check whether our baseline estimates for adopted children change upon the inclusion of controls for the education and income levels of the biological parents (row 4) and the adoptive parents (row 5) respectively. The results hardly change. All in all, our sensitivity analysis

\footnotetext{
${ }^{23}$ We estimate regressions of adoptive parent entrepreneurship status on the biological parents' entrepreneurship status in three specifications: (i) no controls, (ii) the same birth year and county controls as in Table 3 and (iii) extra controls for education levels (dummies) and incomes of the biological and adoptive parents, see Appendix Table A1. It shows that the resulting coefficients are zero suggesting that non-random placement with respect to entrepreneurship status is no issue.
} 
shows no evidence of nonrandom placement in terms of entrepreneurship nor does nonrandom placement in terms of education and income affect our results.

\subsubsection{Age at Adoption}

A non-trivial share of our sample of adopted children may have experienced post-delivery placements longer than 12 months (see Section 3.1). If late placements affect later outcomes in a manner that is different from direct placements in the adopting family, then we may be underestimating the post-birth effects of these children's adopting parents, or overestimate the pre-birth effects of parents who adopt away. However, we do not see this as overly problematic, given that our main message is that nurture matters more than nature.

\subsubsection{Non-linearities}

Non-linear effects could influence our estimates of pre- and post-birth factors. We can allow for non-linearities by interacting the entrepreneurship status of the biological parents with the status of the adoptive parents (i.e. allowing for gene-environment interactions). For example, a positive interaction effect would indicate that pre- and post-birth factors are complements in the production of child entrepreneurship. That is, children with entrepreneurial birth parents who are adopted by entrepreneurial adoptive parents are even more likely to become entrepreneurs than a similar child who is adopted by non-entrepreneurial parents.

We re-estimate the baseline regressions for adoptees while including an interaction term that is equal to one when both sets of parents include at least one entrepreneur (row (6), columns 1 and 2), when both fathers are entrepreneur (row (6), columns 3 and 4) and when both mothers are entrepreneur (row (6), columns 5 and 6). The coefficients belonging to the interacted terms are all zero (not tabulated), implying no significant interaction between preand post-birth entrepreneurial backgrounds. The other estimates are similar to the baseline 
results.

\subsubsection{Reverse Causality}

In most adoption studies, parents outcomes are determined before the children's. In our study, however, we are observing parents' and their children's outcomes contemporaneously. Could it be that children's entrepreneurship affects their parents' decision to become entrepreneurs? In our data, we find that 50 percent of all fathers and 40 percent of all mothers who are entrepreneurs are observed as entrepreneurs already in 1985 (the first year that we have data for), while only 8 to 15 percent of all entrepreneurial children are entrepreneurs in 1985. Also, we can see in our data that 59 percent of all entrepreneurial mothers and 63 percent of all entrepreneurial fathers have their first year as an entrepreneur before their child has his or her first year as an entrepreneur. These two facts speak against reverse causality, although not conclusively. To further investigate the direction of causality we have also run a set of Granger causality tests. These tests confirmed the notion that the parent-offspring association in entrepreneurship is mainly driven by the influence that parents have on their children and not vice-versa. ${ }^{24}$

\subsection{External validity}

In this section, we address the validity of the underlying assumptions that ensure the external validity of our results. What we want to know is whether it is reasonable to generalize the results from our selected sample of adoptees to the population at large. We investigate four potential problems: (i) many adoptees have unknown fathers, (ii) pre-birth characteristics of adopted children may differ from those of own-birth children, (iii) adoptive parents may be different from birth parents of non-adopted children, and (iv) adoptive parents may treat their

\footnotetext{
${ }^{24}$ The results from the Granger causality tests are available upon request.
} 
children differently than own-birth parents do. The results are summarized in the following Subsections and in Table 5.

\subsubsection{Unknown Fathers}

Our estimates may be biased due to restricting the sample of adoptees to those for whom data are available for both of the biological parents. This restriction is substantial, for more than half of the adoptees the information on the biological fathers is missing. Row (7) of Table 5 shows the results of re-estimating the effects of the entrepreneurship status of biological and adoptive mothers on the adoptees' outcome for the extended set of adoptees. The estimated coefficients hardly change and the effect of the biological mother becomes significant due to the larger sample size.

\subsubsection{Comparable Samples}

The parents of adopted children may be different from the parents of own-birth children. Adoptive parents tend to be somewhat older, higher educated, and earn higher incomes than average (see Table 2). On the contrary, parents who adopt away their children tend to be younger, lower educated, and earn lower incomes than average. In case these differences affect our estimates, the comparison between adopted and non-adopted children becomes problematic. To investigate whether our baseline results for adoptees are a reasonable comparison to non-adoptees, and thus externally valid, we re-estimate the baseline equations for non-adoptees using two different, more comparable samples. The first sample addresses the issue that adoptive parents tend to be positively selected, i.e., adopted children may face advantageous post-birth environments. It consists of own-birth children and their parents, where we require that the parents have similar observables to those of adoptive parents. Likewise, the second new sample consists of own-birth children and their parents, where the 
parents are required to have similar observables to the biological parents of adopted children.

This sample addresses the issue that adoptees may be endowed with less advantageous prebirth characteristics, since biological parents tend to be negatively selected. Both samples are created using a propensity score matching method. ${ }^{25}$

Rows (9) and (10) of Table 5 present the results of re-estimating our baseline intergenerational association of entrepreneurship for these new samples of own-birth children and parents. The results are very similar to the baseline results for non-adopted children (row (8) of Table 5). They all fall within the ranges of the summed effects of biological and adoptive parents for adoptees that were indicated in the bottom panel of Table $3 .{ }^{26}$ As far as can be judged from propensity matching on observable characteristics, our baseline estimates are not sensitive to the fact that adopted children and their adoptive parents are different from own-birth children and their parents: These differences do not translate into meaningful changes in the estimated intergenerational association in entrepreneurship.

\subsubsection{Differential treatment}

In order to generalize our findings from adopted children to all children, we need to assume that adoptive parents do not treat their adopted children differently from how biological parents treat their own-birth children (nor should adoptees respond systematically different from own-birth children to the received parenting). While this is not something that one can easily test directly, we can examine the parent-offspring associations found in the small

\footnotetext{
${ }^{25}$ We employed a nearest neighbor matching method without replacement. In case of a tie, we included both neighbors. Adopted children were matched to own-birth children using an estimated propensity score. The propensity score was estimated using a probit model with adopted $(\mathrm{yes}=1, \mathrm{no}=0)$ as the dependent variable. Regressors included the child's birth year, gender, mother's age at child's birth, father's age at child's birth, mother's income, father's income, mother's education, father's education, mother's entrepreneurship status and father's entrepreneurship status. When estimating the propensity score for our first sample of "positively" selected parents, we matched biological parents with own-birth children to adoptive parents. When estimating the score for our second sample of "negatively" selected parents, we matched biological parents with own-birth children to the biological parents of adopted away children.

${ }^{26}$ The coefficient in row 10 for the negatively selected group of fathers of own-birth children changes, however, quite a bit (two percentage points).
} 
number of families in which both adopted children and own-birth children live together and share a common set of parents. We do not find significant differences between the parentoffspring associations in entrepreneurship and the summed biological and adoptive parent estimates for 250 and 217 own-birth children and adoptees, respectively. Unfortunately, the sample size does not allow a firm conclusion about differential treatment of adopted children versus own-birth children.

\section{An Exploration of Potential Post-Birth Mechanisms}

Thus far, we have learned that post-birth factors account for more of the intergenerational transfer of entrepreneurship among adoptees than pre-birth factors do. But what exactly is this entrepreneurial "nurture" effect? In this section, we explore the plausibility of several candidate explanations that exist in the literature (recall our discussion in the introduction).

First, children may eventually inherit the family business. Previous studies find that inheritance is generally not large enough to explain much of the intergenerational transfer of entrepreneurship (Parker 2009, Aldrich, Renzulli, and Langton 1998, Sørensen, 2007). In this paper, we can only measure an upper bound of the probability that a business was obtained through inheritance by using the indirect method proposed by Sørensen (2007). He addresses inheritance indirectly with Danish panel data; nearly $8 \%$ of the children's entries into selfemployment occur at the same time and in the same industry as the parents' exit. In our data, only $2.2 \%$ of all entrepreneurs enter for the first time in the same industry as their parent and in the same year as their parent exits entrepreneurship. If we broaden this measure to include offspring that become an entrepreneur one year before or after their parent's exit, then this number rises to $4.4 \%$. If we expand this to include offspring whose first stint as an entrepreneur is in the same industry as their parent's last stint as an entrepreneur (regardless of the timing of entry and exit), then this number rises to $9.3 \%$. This is clearly an over 
estimation of the percentage of children who inherit the family business, since it includes all persons ending up in the same industry as their parents for whatever reason.

The second mechanism is that children of entrepreneurs may have access to 'cheaper' capital. Table 6 addresses this mechanism in more detail. Column (1) shows the baseline post-birth that we want to explain. ${ }^{27}$ In column (2) we control for adoptive parents income, whereas column (3) includes a proxy for parental wealth, which is a dummy variable equal to one if either of the child's parents is in the top decile of pre-tax total factor income and zero otherwise. These control variables have no impact whatsoever on our estimate of the postbirth association. Thus, access to 'cheap' capital does not explain the "nurturing” effect.

The third mechanism is that entrepreneurial parents may provide their children with general business human capital and, thereby, enhancing their prospects as entrepreneurs. This cannot be tested directly in the realm of our study. However, two observations speak against this hypothesis. First, as was shown in Table 5, adding parental education and income variables - as indirect proxies of general business human capital - to the basic equation does not change the main result. Second, the discussion of Table 4 indicated that children of entrepreneurs do not systematically outperform other entrepreneurs.

The fourth mechanism is that parents may pass on occupation- and/or industry-specific skills to their children. This is tested in column (4) of Table 6 by adding controls for two-digit industry codes for where mothers and fathers work as proxies for their occupations. Alternatively, if the share of entrepreneurs tends to be higher in some occupations than in others (e.g., plumbers or dentists), and if occupations are correlated across generations, then this could lead to a correlation in entrepreneurship across generations. The inclusion of industry dummies lowers the nurturing effect of fathers by $10 \%$, but has no effect on the

\footnotetext{
${ }^{27}$ The post-birth association for adoptive fathers is 0.089 and for adoptive mothers it is 0.91 . These coefficients are slightly different from those reported in Table 3, as column (1) only includes the information on adoptive parents.
} 
nurturing effect of mothers. This suggests that (at most) a small proportion of the adoptive parent-child correlation can be explained in terms of the transfer of occupation-specific skills (or, in our case, industry-specific).

In summary, Table 6 presents an initial attempt to explain the strong adoptive parentchild association that we find in this study. We show that a small part of this association may be due to the transfer of occupation-specific skills (actually, industry-specific) and argue that it is unlikely that inheritances of businesses, parental wealth or the acquisition of general business human capital explain any significant part of the post-birth association that we find. Next, we turn to parental role modeling.

\subsection{Parents as Role Models}

We address role modeling by allowing the effects of entrepreneurial fathers and mothers to vary for daughters and sons. A stronger same sex transmission of entrepreneurship can be seen as an indication of the presence of role modeling (Andersson and Hammarstedt, 2011). Namely, based on role model identification theory and homophily, role models are more often of the same gender (Ruef et al. 2003). More specifically, if the nurture part of the parent-child association is particularly strong for mothers and their daughters on the one hand, and for fathers and their sons on the other hand, we could view this as evidence of role modeling (Andersson and Hammarstedt, 2011). An alternative interpretation of a stronger same sex transmission is that it results from different behavior of parents towards same sex children. For example, Thomas (1994) finds that mothers invest more in the education of their daughters, and fathers channel more resources towards their sons.

In Table 7, we show the results from various tests related to this role modeling hypothesis. The top panel shows the results from estimating the transmission of the entrepreneurship status of adoptive parents to their children, for daughters and sons separately, 
where each column reflects a separate regression equation. The bottom panel shows the results for the parents of own-birth children. These are interesting as well for testing our role modeling hypothesis since the 'nature' part of this relationship is not likely to be different for boys and girls. Furthermore, the sample of own-birth children is much larger and is therefore helpful to generate more precise estimates of the differential nurturing effects of fathers and mothers on sons and daughters.

Column (1) of Table 7 shows what we call the basic result for the role modeling exercise. The only controls included are the county dummies for the children and the birth year dummies of the children and their rearing parents. The left hand side of the upper panel shows that the transmission of entrepreneurship from adoptive parents to girls goes exclusively via the mother. The right hand side shows that the strongest effect for boys is caused by the father. The single sided F-tests show that the differences between the positive coefficients pertaining to the father's and mother's entrepreneurship status dummies are significant (at the 10\%-level) in the expected direction, for both girls and boys.

The bottom half of the first column shows comparable results for the larger sample of own-birth children. In this case, parents affect the entrepreneurship status of the children, through a combination of pre- and post-birth factors. The difference though is clear: fathers affect sons more strongly, whereas for daughters the effect of the mother is significantly larger. ${ }^{28}$ The summed percentage effects of fathers and mothers on the likelihood of entrepreneurship are strikingly similar for boys and girls. Note that, Table 2 showed us that entrepreneurship is almost twice as likely among boys, so in order to compare the effects of either parent in percent increase one needs to double the coefficients for girls.

\footnotetext{
${ }^{28}$ This finding supports the results of Andersson and Hammarstedt (2011): they also find that intergenerational entrepreneurship is affected by both parents, but more strongly by the parent of the same sex (in the sample of Swedish natives, see their Table 5).
} 
Column (2) includes controls for labor market characteristics of the nurturing parents. The estimates resemble those from the baseline role modeling exercise in column (1), which might have been expected based on the results shown in Tables 5 and 6 . This suggests we find a direct 'entrepreneurship' role modeling effect rather than an indirect effect through occupational choice or education that is transmitted from fathers (mothers) to sons (daughters). Column (3) includes the entrepreneurship status and birth year dummies of the set of birth parents who adopt away and mimics the baseline role modeling result.

Finally, in Column (4) we try to distinguish between our role modeling interpretation of the stronger same sex transmission and the alternative explanation that parents invest more in their children of the same sex. We do so by including the (mean centered) number of sisters (brothers) and an interaction term with the entrepreneurship status of the mother (father) in the estimation for girls (boys): If the same sex parent-child transmission of entrepreneurship is driven by differential parenting efforts, one would expect a negative interaction effect. That is, the effect of having an entrepreneur for a father is stronger for sons that do not have to share their father's attention with a brother, whereas this should have no impact on the transmission under our role-modeling explanation.

Our findings from Column (1) to (3) remain largely unchanged when we allow the same sex parent-child transmission of entrepreneurship to vary by the number of same sex siblings. In our sample of adoptees we do not find any support for the interpretation of stronger same sex parenting efforts; the interaction term in the girls equation is insignificant, while for boys it is significant, but positive. In the larger sample of own-birth children, there is indication that the same sex parent-child transmission of entrepreneurship is diminishing with the number of same sex siblings. However, the mothers still affect daughters more strongly, whereas for sons the effect of the father is larger. The same sex parent-child transmission 
remains stronger as long as girls do not have more than two sisters and boys do not have more than two brothers (which holds for 91 percent of our sample).

All in all, Table 7 shows that the entrepreneurship transmission effect of the same sex nurturing parent is consistently larger than of the other sex nurturing parent. Moreover, the difference cannot be fully explained by differences in parenting efforts. We consider this evidence of role modeling.

\section{Conclusion}

Questions concerning the origins of entrepreneurship have attracted a lot of attention, and for good reasons. Entrepreneurship has important economic and social benefits, that could potentially justify both private and public spending on entrepreneurial training, business school educations, and public programs aimed at promoting entrepreneurship. The true value of these policies, however, cannot be judged correctly without more information concerning the origins and malleability of entrepreneurship.

The most unambiguous and least debated stylized fact emerging from entrepreneurship economics concerning the origins of entrepreneurship is the high correlation between the entrepreneurial choices of parents and their children. The chance of becoming an entrepreneur is 1.3 to 3 times larger for children whose fathers or mothers have been entrepreneurs (Andersson and Hammarstedt 2010, Arum and Mueller 2004, Colombier and Masclet 2008, and Dunn and Holtz-Eakin 2000). ${ }^{29}$ We present a similar estimate (1.6 times larger) using a large and representative sample of the Swedish population.

The key question our paper addresses is to what extent this strong intergenerational transmission of entrepreneurship is driven by pre-birth or post-birth factors. In essence, we want to know whether entrepreneurs are born or bred. The larger the contribution of nurture

\footnotetext{
${ }^{29}$ A recent study even indicates a correlation between the entrepreneurial intentions of grandparents and children (Laspita et al., 2012).
} 
vis-à-vis nature, the larger the potential benefit of programs aimed at fostering entrepreneurship.

We identify pre-birth and post-birth factors by analyzing employment histories of Swedish adoptees together with their biological and adoptive parents. Our decomposition exercise reveals a strong correlation of entrepreneurship between both types of parents and their children. In line with recent twin studies, we find evidence of biological underpinnings of entrepreneurship (Nicolaou et al. 2008, Zhang et al. 2009, and Nicolaou and Shane 2010). Our main results, however, shed a different light on the relative importance of pre-birth and post-birth factors. We find that the importance of adoptive parents is twice as large as the influence of biological parents.

A direct comparison of our results with the recent twin studies is not possible, as we address the question of nature versus nurture from a different angle. Twin studies decompose the total variation in entrepreneurship choices into genes, shared and non-shared environment, whereas we decompose the intergenerational association. Thus, twin studies allow for a larger set of environmental influences and they allow pre-birth factors that promote entrepreneurship to be passed on from non-entrepreneurial parents as well. Twin studies find that $40 \%$ of the variance in entrepreneurship choices is explained by genes, and with the exception Zhang et al. (2009), they find no influence of the twins' shared environment. These findings stand in stark contrast to our own findings. In particular, the zero effect of the twins' shared environment is difficult to reconcile with our findings, since shared environment should include most of our important post-birth factors, such as role modeling. Since both adoption studies and twin studies have their own methodological challenges it is important to analyze this important question using both methods. We are the first to do so using the adoption method. We view that as the first contribution of our study. 
Our second contribution is the identification of a parental nurture effect that has a stronger impact on their offspring's choice to become an entrepreneur than the mechanical impact that they have through passing on their genes. Our third contribution is that we explore a set of likely explanation for this important nurturing effect. Previous studies on intergenerational entrepreneurship have identified and measured five environmental mechanisms: (i) the inheritance of a family business, (ii) access to cheaper capital, (iii) less costly acquisition of general business human capital, (iv) the transfer of industry- or firmspecific human capital, and (v) a kind of "catch all" explanation that includes preferences and parental role modeling. In contrast to previous studies, we can explore these different mechanisms while at the same time controlling for genes. We find weak evidence against mechanisms (i) - (iv) and strong (indirect) evidence in favor of parental role modeling. We obtain this result based on an analysis of gender specific parent child transmissions of entrepreneurship.

Our finding that role modeling may be one of the more important mechanisms underlying the parental transmission of entrepreneurship to their offspring deepens our understanding of the role that parents play in fostering entrepreneurship. Moreover, this finding raises a number of intriguing questions relating role modeling to entrepreneurship that could be placed on the research agenda.

Recent empirical evidence indicates that networks and peer groups (e.g., Djankov, Qian, Roland, \& Zhuravskaya, 2006; Nanda \& Sorensen, 2010; Stuart and Ding, 2006) as well as regional inheritances and clusters (Reynolds, Storey and Westhead, 1994; Lafuente, Vailliant, and Rialp, 2007) influence entrepreneurship decisions. This literature suggests that role modeling may be driving these effects. Given our result about the fruitful role of parental role models, further research into the nature and effect of other role models, for instance entrepreneurs in the classroom, in regions, peer groups or networks, might point out the (non- 
)specificity of parental role models and the possible substitution possibilities in the wider social networks of people. 


\section{References}

Acs, Z. J. (1999). Are Small Firms Important? Their Role and Impact. Boston: Kluwer Academic.

Aldrich, H. E., L. A. Renzuli, and N. Langton (1998). Passing on privilege: resources provided by self-employed parents to their self-employed children, Research in Social Stratification and Mobility, Vol. 16: 291-317.

Andersson, L., \& Hammarstedt, M. (2010). Intergenerational transmissions in immigrant selfemployment: Evidence from three generations. Small Business Economics, 34, 261-276.

Andersson, L., \& Hammarstedt, M. (2011). Transmission of self-employment across immigrant generations: the importance of ethnic background and gender. Review of Economics of the Household 34, 261-276.

Arum, R. and W. Mueller (eds.) (2004). The Reemergence of Self-employment: A Comparative Study of Self-employment Dynamics and Social Inequality, Princeton NJ, Princeton University Press.

Barnhuset, A. (1955) Adoption: En vägledning för myndigheter, tjänstemän och förtroendemän, vilka har att syssla med frågor angående adoption, Direktionenen over Allmänna Barnhuset i samråd med Medicinstyrelsen och Socialstyrelsen.

Baron, R., G. Markman. (2003). Beyond social capital: The role of entrepreneurs' social competence in their financial success. Journal of Business Venturing, Vol. 18: 41-60.

Birch, D. (1979). The Job Creation Process. Center for the Study of Neighborhood and Regional Change. Cambridge: MIT Press.

Björklund, A., M. Lindahl, and E. Plug (2006) The Origins of Intergenerational Associations: Lessons from Swedish Adoption Data, Quarterly Journal of Economics Vol. 121: 999 - 1028.

Blanchflower, D. G. and A. J. Oswald (1998). What makes an entrepreneur? Journal of Labor Economics, Vol. 16: 26-60.

Bohman, M. (1970) Adopted Children and Their Families: A Follow-Up Study of Adopted Children, Their Background, Environment and Adjustment, Proprius Förlag, Stockholm.

Bosma, N., J. Hessels, V. Schutjens M. van Praag, and I. Verheul (2012). Entrepreneurship and role models, Journal of Economic Psychology, Vol. 33: 410-424.

Bouchard, T. J. and J. C. Loehlin (2001) Genes, Evolution, and Personality, Behavior Genetics, Vol. 31: 243-273.

Carroll, G. R., and E. Mosakowski, (1987). The career dynamics of self-employment, Administrative Science Quarterly, Vol. 32: 570-589.

Cesarini D., C.T. Dawes, M. Johannesson, P. Lichtenstein and B. Wallace (2009a) Genetic Variation in Preferences for Giving and Risk-Taking, Quarterly Journal of Economics, Vol. 124: 809-842. 
Cesarini D., M. Johannesson, P. Lichtenstein and B. Wallace (2009b) Heritability of Overconfidence, Journal of the European Economic Association, Vol. 7: 617-627.

Cesarini, D., M. Johannesson and S. Oskarsson (2012). Pre-Birth Factors, Post-Birth Factors and Voting: Evidence from Swedish Adoption Data, Unpublished Working Paper.

Colombier, N. and D. Masclet (2008). Intergenerational correlation in self-employment: some further evidence from French ECHP data, Small Business Economics, Vol. 30: 423-37

Corak, M. and P. Piraino (2011) The Intergenerational Transmission of Employers, Journal of Labor Economics, Vol. 29: 37-68.

Djankov, S., Y. Qian, G. Roland, and E. Zhuravskaya (2006). Who Are China's Entrepreneurs? American Economic Review, Vol. 96: 348-352 .

Dohmen, T., A. Falk, D. Huffman and U. Sunde (2012). The Intergenerational Transmission of Risk and Trust Attitudes, Review of Economic Studies, Vol. 79(2): 645-677

Dunn, T. and D. Holtz-Eakin (2000). Financial capital, human capital and the transition to selfemployment: evidence from intergenerational links, Journal of Labor Economics, Vol. 18: 282305

Fairlie, R. W. and A. M. Robb (2007a). Families, human capital, and small business: evidence from the Characteristics of Business Owners Survey, Industrial and Labor Relations Review, Vol. 60: 225-245

Fairlie, R. W. and A. M. Robb (2007b). Why are black-owned businesses less successful than white-owned businesses? The role of families, inheritances and business human capital, Journal of Labor Economics, Vol. 25: 289-323

Hjalmarsson, R. and M. J. Lindquist (forthcoming). Labour Economics.

Klapper, L., L. Laeven and R. Rajan (2006). Entry regulation as a barrier to entrepreneurship, Journal of Financial Economics, 82, pp. 591-629

Koellinger, P., Minniti, M. and Schade, C. (2007). I think I can, I think I can: Overconfidence and entrepreneurial behavior, Journal of Economic Psychology, Vol. 28: 502-527.

Koellinger, P. D., M. J. H. M. van der Loos, P. J. F. Groenen, A. R. Thurik • F. Rivadeneira F. J. A. van Rooij A. G. Uitterlinden, and A. Hofman (2010) Genome-wide association studies in economics and entrepreneurship research: promises and limitations, Small Business Economics, Vol. 35: 1-18.

Koellinger et al. (2012) “The Molecular Genetics of Serial Self-Employment", unpublished manuscript.

Laband, D. N. and B. F. Lentz (1983) Like Father, like Son: Toward an Economic Theory of Occupational Following, Southern Economic Journal, Vol. 50: 474-493.

Lafuente, E., Y. Vailliant, and J. Rialp (2007). Regional Differences in the Influence of Role Models: Comparing the Entrepreneurial Process of Rural Catalonia, Regional Studies, Vol. 41: $779-796$. 
Lentz, B. F. and D. N. Laband (1990). Entrepreneurial success and occupational inheritance among proprietors, Canadian Journal of Economics, Vol. 23: 563-79

McPherson, M., Smith-Lovin, L. and Cook, J. (2001). Birds of a feather: Homophily in social networks. Annual Review of Sociology, Vol. 27: 415-444

Moore, R. L. (1983). Employer Discrimination: Evidence from Self-Employed Workers, Review of Economics and Statistics, Vol. 65: 496-501.

Nanda, R. and J. B. Sørensen (2010) Workplace Peers and Entrepreneurship, Management Science, Vol. 56, pp. 1116-1126.

Nicolaou, N., S. Shane, L. Cherkas, J. Hunkin, and T. D. Spector (2008) Is the tendency to engage in entrepreneurship genetic? Management Science, Vol. 54: 167-179.

Nicolaou, N. and S. Shane (2009) Can genetic factors influence the likelihood of engaging in entrepreneurial activity? Journal of Business Venturing, Vol. 24: 1-22.

Nicolaou, N. and S. Shane (2010) Entrepreneurship and occupational choice: Genetic and environmental influences, Journal of Economic Behavior \& Organization, Vol. 76: 3-14.

Nicolaou, N. and S. Shane (2011) The genetics of entrepreneurship, in D. B. Audretsch. O. Falck, S. Heblich, and A. Lederer (eds.) Handbook of Research on Innovation and Entrepreneurship, Cheltenham: Edward Elgar.

Nordlöf, B. (2001) Svenska adoptioner i Stockholm 1918-1973, FoU-rapport 2001:8, Socialtjänstförvaltningen.

Parker, S. (2009). The Economics of entrepreneurship, Cambridge University Press, Cambridge, UK.

Reynolds, P.D., Storey, D. and Westhead, P. (1994). Cross-national comparisons of the variation in new firm formation rates, Regional Studies, Vol. 28: 443-456.

Roberts, E. B. (1991). Entrepreneurs in high technology, New York: Oxford University Press.

Ruef, M., H.E. Aldrich, and N.C. Carter (2003) The structure of founding teams: homophily, strong ties, and isolation among U.S. entrepreneurs, American Sociological Review, Vol. 68: 195-222.

Shane, S. (2009). Why encouraging more people to become entrepreneurs is bad public policy. Small Business Economics, Vol. 33: 141-149.

Sørensen, J. B. (2007). Closure and Exposure: Mechanisms in the Intergenerational Transmission of Self-employment." Research in the Sociology of Organizations, Vol. 25: 83124.

Storey, D. J. (2006). Evaluating SME policies and programmes: Technical and political dimensions, in M. Casson, B. Yeung, A. Basu and N. Wadeson (eds.), The Oxford Handbook of Entrepreneurship, Oxford, Oxford University Press, pp. 248-78

Stuart, T. E. and W. W. Ding (2006). When Do Scientists Become Entrepreneurs? The Social 
Structural Antecedents of Commercial Activity in the Academic Life Sciences, American Journal of Sociology, Vol. 1: 97-144.

Thomas, D. (1994) Like Father, like Son; Like Mother, like Daughter: Parental Resources and Child Height, Journal of Human Resources, Vol. 29, 950-988.

Tsou, M. W., J. T. Liu, and J. K. Hammit (2012) "The intergenerational transmission of education: Evidence from Taiwanese adoptions," Economics Letters 115(1), 134-136.

Van Praag, M. and P. Versloot (2007) What is the value of entrepreneurship? A review of recent research, Small Business Economics, vol. 29(4), 351-382

Vollebergh, W. A. M., J. Idema, and Q. A. W. Raaijmakers (2001). Intergenerational transmission and the formation of cultural orientations in adolescence and young adulthood. Journal of Marriage and the Family, Vol. 63: 1185-1198.

Zhang, Z., M. Zyphur, J. Narayanan, R. Arvey, S. Chaturvedi, B. Avolio, P. Lichtenstein, G. Larsson (2009). The genetic basis of entrepreneurship: Effects of gender and personality, Organizational Behavior and Human Decision Processes, 110, 93-107. 
Sample Restriction

(1) All individuals adopted by at least one parent

(2) Keep Only those Adopted by both parents (and both are identified)

(3) All non-adopted individuals

(4) All index non-adopted individuals

(5) Exclude children born abroad

(6) Exclude children with one or more parents born before 1920

(7) Exclude all children who died or emigrated from Sweden before 1985

(8) Exclude all children with one or more parents who died or emigrated from Sweden before 1985

(5) Exclude children born 1970 or later

(10) Exclude children with biological mothers missing

(11) Keep those for whom both biological parents are identified

\section{Non-}

Adoptees

Adoptees

Changes in

Non-Adoptees

Changes in

Adoptees

143,490

91,447

$-52,043$

$7,408,044$

$2,448,405$

$-4,959,639$

$1,987,817$

46,807

$-460,588$

$-44,640$

$1,524,512$

20,720

$-463,305$

$-26,087$

$1,491,342$

20,540

$-33,170$

$-180$

$1,437,623$

17,639

$-53,791$

$-2,901$

10,000

$-987,873$

$-7,639$

422,389

8,513

$-27,361$

$-1,487$

$412,183 \quad 3,941$

$-10,206$

$-4,572$ 
Table 2a. Descriptive Statistics: means and standard deviations

\begin{tabular}{|c|c|c|c|c|}
\hline & \multicolumn{2}{|c|}{ Own-birth children } & \multicolumn{2}{|c|}{ Adopted children } \\
\hline & Mean & $S D$ & Mean & $S D$ \\
\hline \multicolumn{5}{|l|}{ Daughters } \\
\hline$\overline{\text { Entrepreneur }}$ & 0.14 & 0.35 & 0.14 & 0.35 \\
\hline Incorporated & 0.04 & 0.20 & 0.04 & 0.20 \\
\hline Entrepreneurial Income $\mathrm{a}^{\mathrm{a}}$ & 11.54 & 0.95 & 11.54 & 1.00 \\
\hline Income & 11.70 & 0.46 & 11.64 & 0.48 \\
\hline Years of Schooling & 12.40 & 2.23 & 12.22 & 2.00 \\
\hline Age in $1985^{\mathrm{b}}$ & 24.9 & 6.44 & 22.3 & 4.28 \\
\hline \multicolumn{5}{|l|}{ Sons } \\
\hline Entrepreneur & 0.25 & 0.43 & 0.23 & 0.42 \\
\hline Incorporated & 0.11 & 0.31 & 0.08 & 0.26 \\
\hline Entrepreneurial Income & 11.85 & 0.85 & 11.71 & 0.82 \\
\hline Income & 12.02 & 0.49 & 11.90 & 0.51 \\
\hline Years of Schooling & 11.96 & 2.33 & 11.67 & 1.99 \\
\hline Age in 1985 & 24.9 & 6.45 & 22.5 & 4.44 \\
\hline Mothers & \multicolumn{4}{|c|}{ Birth Parents } \\
\hline$\overline{\text { Entrepreneur }}$ & 0.15 & 0.36 & 0.10 & 0.30 \\
\hline Incorporated & 0.02 & 0.15 & 0.02 & 0.13 \\
\hline Entrepreneurial Income & 11.58 & 0.84 & 11.37 & 0.97 \\
\hline Income & 11.57 & 0.57 & 11.59 & 0.51 \\
\hline Years of Schooling & 9.52 & 2.72 & 9.37 & 2.46 \\
\hline Age in 1985 & 50.7 & 7.38 & 45.5 & 6.73 \\
\hline \multicolumn{5}{|l|}{ Fathers } \\
\hline Entrepreneur & 0.26 & 0.44 & 0.20 & 0.40 \\
\hline Incorporated & 0.05 & 0.21 & 0.04 & 0.20 \\
\hline Entrepreneurial Income & 12.05 & 0.70 & 11.80 & 0.92 \\
\hline Income & 12.21 & 0.45 & 11.96 & 0.48 \\
\hline Years of Schooling & 9.69 & 2.98 & 9.17 & 2.52 \\
\hline Age in 1985 & 53.5 & 7.38 & 48.6 & 7.24 \\
\hline Mothers & \multicolumn{4}{|c|}{ Adoptive Parents } \\
\hline Entrepreneur & & & 0.15 & 0.36 \\
\hline Incorporated & & & 0.02 & 0.15 \\
\hline Entrepreneurial Income & & & 11.67 & 0.74 \\
\hline Income & & & 11.54 & 0.56 \\
\hline Years of Schooling & & & 9.67 & 2.83 \\
\hline Age in 1985 & & & 53.6 & 5.97 \\
\hline \multicolumn{5}{|l|}{ Fathers } \\
\hline$\overline{\text { Entrepreneur }}$ & & & 0.27 & 0.45 \\
\hline Incorporated & & & 0.04 & 0.20 \\
\hline Entrepreneurial Income & & & 12.22 & 0.65 \\
\hline Income & & & 12.33 & 0.43 \\
\hline Years of Schooling & & & 10.20 & 3.10 \\
\hline Age in 1985 & & & 55.9 & 5.77 \\
\hline
\end{tabular}

(a) Entrepreneurial Income is only reported for those with Entrepreneur $=1$. (b) Our data on self employment start in 1985. 


\begin{tabular}{|c|c|c|c|c|c|c|}
\hline & & \multicolumn{5}{|c|}{ Own-birth children } \\
\hline & & 1 & & 2 & & 3 \\
\hline 1 & Respondent Entrepreneur & 1.000 & & & & \\
\hline 2 & Biological father Entrepreneur & $0.120^{*}$ & & 1.00 & & \\
\hline \multirow[t]{3}{*}{3} & Biological mother Entrepreneur & $0.112 *$ & & $0.381 *$ & & 1.00 \\
\hline & & \multicolumn{5}{|c|}{ Adopted children } \\
\hline & & 4 & 5 & 6 & 7 & 8 \\
\hline \multirow[t]{2}{*}{4} & & 1.000 & & & & \\
\hline & Respondent Entrepreneur & & & & & \\
\hline \multirow[t]{2}{*}{5} & & $0.045^{*}$ & 1.000 & & & \\
\hline & Biological father Entrepreneur & & & & & \\
\hline 6 & Biological mother Entrepreneur & 0.025 & $0.065^{*}$ & 1.000 & & \\
\hline 7 & Adoptive father Entrepreneur & $0.090^{*}$ & 0.002 & 0.009 & 1.000 & \\
\hline 8 & Adoptive mother Entrepreneur & $0.079 *$ & 0.005 & -0.027 & $0.416^{*}$ & 1.000 \\
\hline
\end{tabular}


Table 3: Baseline results, ever been an entrepreneur

\begin{tabular}{|c|c|c|c|c|}
\hline & (1) & (2) & (3) & (4) \\
\hline $\begin{array}{l}\text { Own-Birth Children } \\
\text { Entrepreneur_Bioparent }\end{array}$ & $\begin{array}{c}0.116^{* * * *} \\
{[.001]} \\
(61 \%)\end{array}$ & & & \\
\hline Entrepreneur_Biofather & & $\begin{array}{c}0.115 * * * \\
{[.002]} \\
(61 \%)\end{array}$ & & $\begin{array}{c}0.088 * * * \\
{[0.002]} \\
(46 \%)\end{array}$ \\
\hline Entrepreneur_Biomother & & & $\begin{array}{c}0.128 * * * \\
{[0.002]} \\
(67 \%) \\
\end{array}$ & $\begin{array}{c}0.089 * * * \\
{[0.002]} \\
(47 \%) \\
\end{array}$ \\
\hline $\begin{array}{l}\text { Adopted Children } \\
\text { Entrepreneur_Bioparent }\end{array}$ & $\begin{array}{c}0.037 * * \\
{[0.015]} \\
(19 \%)\end{array}$ & & & \\
\hline Entrepreneur_Biofather & & $\begin{array}{c}0.042 * * \\
{[0.017]} \\
(22 \%)\end{array}$ & & $\begin{array}{c}0.043 * * \\
{[0.017]} \\
(23 \%)\end{array}$ \\
\hline Entrepreneur_Biomother & & & $\begin{array}{c}0.034 \\
{[0.023]} \\
(18 \%)\end{array}$ & $\begin{array}{c}0.030 \\
{[0.023]} \\
(16 \%)\end{array}$ \\
\hline Entrepreneur_Adparent & $\begin{array}{c}0.084 * * * \\
{[0.014]} \\
(44 \%)\end{array}$ & & & \\
\hline Entrepreneur_Adfather & & $\begin{array}{c}0.087 * * * \\
{[0.015]} \\
(46 \%)\end{array}$ & & $\begin{array}{c}0.069 * * * \\
{[0.016]} \\
(36 \%)\end{array}$ \\
\hline Entrepreneur_Admother & & & $\begin{array}{c}0.093 * * * \\
{[0.019]} \\
(49 \%) \\
\end{array}$ & $\begin{array}{c}0.065^{* * *} * \\
{[0.021]} \\
(34 \%) \\
\end{array}$ \\
\hline $\begin{array}{l}\text { Sum of biological and } \\
\text { adoptive parent coefficients }\end{array}$ & $\begin{array}{c}0.121 \\
{[0.021]} \\
0.080-0.161\end{array}$ & & & \\
\hline $\begin{array}{l}\text { Sum of biological and } \\
\text { adoptive father coefficients }\end{array}$ & & $\begin{array}{c}0.129 \\
{[0.022]} \\
0.085-0.173\end{array}$ & & $\begin{array}{c}0.112 \\
{[0.023]} \\
0.066-0.158\end{array}$ \\
\hline $\begin{array}{l}\text { Sum of biological and } \\
\text { adoptive mother coefficients }\end{array}$ & & & $\begin{array}{c}0.128 \\
{[0.030]} \\
0.069-0.186\end{array}$ & $\begin{array}{c}0.095 \\
{[0.032]} \\
0.033-0.156\end{array}$ \\
\hline $\begin{array}{l}\text { F-Test of differential effects of } \\
\text { bio- and adoptive parents }{ }^{\mathrm{a}}\end{array}$ & $4.97 * *$ & $4.25^{* *}$ & $4.10 * *$ & $3.13^{*}$ \\
\hline Year of Birth dummies Child & YES & YES & YES & YES \\
\hline Year of birth dummies Parents & YES & YES & YES & YES \\
\hline $\begin{array}{l}\text { Year County of Residence } \\
\text { Dummies Child in } 1965\end{array}$ & YES & YES & YES & YES \\
\hline $\begin{array}{l}\text { Biological Observations } \\
\text { Adoptive Observations }\end{array}$ & $\begin{array}{c}412183 \\
3941\end{array}$ & $\begin{array}{c}412183 \\
3941\end{array}$ & $\begin{array}{c}412183 \\
3941\end{array}$ & $\begin{array}{c}412183 \\
3941\end{array}$ \\
\hline
\end{tabular}

All (OLS-)estimations include a gender dummy for the child. Robust standard errors are given between brackets. The percentages between parentheses convert the estimates from percentage points to percentage as compared to the prevalence of entrepreneurship in the relevant sample of children (19\% for both samples, see Table 2).

${ }^{a}$ Column 4 presents the F-test of a differential effect of the summed birth parent coefficients versus the adoptive parents coefficients. Separate tests for the fathers and mothers cannot reject that bio- and adoptive parents are the same. 
Table 4: Replication of Table 3 with stricter definitions of entrepreneurship

\begin{tabular}{|c|c|c|c|c|c|}
\hline & (1) & $(2)$ & $(3)$ & (4) & $(5)$ \\
\hline Definition of & $\begin{array}{l}\text { Entrepreneu } \\
\text { Baseline }\end{array}$ & $\begin{array}{l}\text { Entrepreneur_ } \\
\text { Incorporated }\end{array}$ & $\begin{array}{l}\text { Entrepreneur } \\
>=3 \text { years }\end{array}$ & $\begin{array}{l}\text { Entrepreneur_ } \\
\text { Higher income }\end{array}$ & $\begin{array}{l}\text { Entrepreneur } \\
>=3 \text { years \& } \\
\text { Higher income }\end{array}$ \\
\hline $\begin{array}{l}\text { \%entrepreneurs } \\
\text { in definition }\end{array}$ & $100 \%$ & $40 \%$ & $70 \%$ & $70 \%$ & $50 \%$ \\
\hline PART A & \multicolumn{5}{|c|}{ Stricter definitions of entrepreneurship apply to children only } \\
\hline \multicolumn{6}{|c|}{ Own-birth Children } \\
\hline \multicolumn{6}{|c|}{ Entrepreneur_bio } \\
\hline $\mathrm{p}$ & $0.116^{* * *}$ & $0.048 * * *$ & $0.095 * * *$ & $0.060 * * *$ & $0.051 * * *$ \\
\hline & {$[0.001]$} & {$[0.001]$} & {$[0.001]$} & {$[0.001]$} & {$[0.001]$} \\
\hline & $61 \%$ & $66 \%$ & $71 \%$ & $45 \%$ & $52 \%$ \\
\hline \multicolumn{6}{|l|}{ Adopted } \\
\hline \multirow{3}{*}{$\begin{array}{l}\text { Entrepreneur } \\
\text { Bioparent }\end{array}$} & $0.037 * *$ & 0.000 & $0.021^{*}$ & $0.020 *$ & 0.008 \\
\hline & {$[0.015]$} & [0.009] & [0.013] & [0.012] & [0.009] \\
\hline & $19 \%$ & $0 \%$ & $16 \%$ & $15 \%$ & $8 \%$ \\
\hline \multirow{3}{*}{$\begin{array}{l}\text { Entrepreneur_ } \\
\text { Adparent }\end{array}$} & $0.084 * * *$ & $0.031 * * *$ & $0.069 * * *$ & $0.044 * * *$ & $0.034 * * *$ \\
\hline & {$[0.014]$} & [0.009] & {$[0.012]$} & {$[0.011]$} & [0.009] \\
\hline & $44 \%$ & $43 \%$ & $52 \%$ & $33 \%$ & $34 \%$ \\
\hline bio-+adoptive & $0.121 * * *$ & $0.031 * *$ & $0.090 * * *$ & $0.064 * * *$ & $0.042 * * *$ \\
\hline \multirow{2}{*}{ parent coeff } & [0.02] & {$[0.012]$} & {$[0.018]$} & {$[0.016]$} & {$[0.013]$} \\
\hline & $.08-.16$ & $.01-.06$ & $.06-.12$ & $.03-.09$ & $.02-.07$ \\
\hline $\begin{array}{l}\text { F-Test bio- minus } \\
\text { adoptive parent } \\
\text { coeff }\end{array}$ & $4.97 * *$ & $5.87 * *$ & $7.21 * * *$ & 2.19 & $3.61^{*}$ \\
\hline PART B & \multicolumn{5}{|c|}{ Stricter definitions of entrepreneurship apply to children and parents } \\
\hline \multicolumn{6}{|c|}{ Own-birth Children } \\
\hline Entrepreneur_ & $0.116^{* * * *}$ & $0.159 * * *$ & $0.101 * * *$ & $0.061 * * *$ & $0.057 * * *$ \\
\hline Bioparent & {$[0.001]$} & {$[0.003]$} & {$[0.001]$} & {$[0.001]$} & {$[0.001]$} \\
\hline & $61 \%$ & $209 \%$ & $76 \%$ & $46 \%$ & $58 \%$ \\
\hline \multicolumn{6}{|l|}{ Adopted } \\
\hline Entrepreneur_ & $0.037 * *$ & 0.021 & 0.019 & 0.013 & 0.006 \\
\hline \multirow{2}{*}{ Bioparent } & {$[0.015]$} & [0.019] & [0.014] & [0.014] & [0.014] \\
\hline & $19 \%$ & $28 \%$ & $14 \%$ & $10 \%$ & $6 \%$ \\
\hline Entrepreneur_ & $0.084 * * *$ & $0.171 * * *$ & $0.068 * * *$ & $0.031 * *$ & $0.032 * * *$ \\
\hline \multirow{2}{*}{ Adparent } & {$[0.014]$} & {$[0.031]$} & {$[0.013]$} & {$[0.012]$} & {$[0.012]$} \\
\hline & $44 \%$ & $225 \%$ & $51 \%$ & $23 \%$ & $32 \%$ \\
\hline bio-+adoptive & $0.121 * * *$ & $0.192 * * *$ & $0.087 * * *$ & $0.044^{* *}$ & $0.038^{* *}$ \\
\hline \multirow[t]{2}{*}{ parent coeff } & [0.02] & {$[0.037]$} & [0.019] & {$[0.019]$} & {$[0.017]$} \\
\hline & $.08-.16$ & $.12-.26$ & $.05-.12$ & $.01-.08$ & $.00-.07$ \\
\hline $\begin{array}{l}\text { F-Test bio- minus } \\
\text { adoptive parent } \\
\text { coeff }\end{array}$ & $4.97 * *$ & $17.57 * * *$ & $5.98 * *$ & 0.90 & 1.92 \\
\hline \# Non-adopted & 412183 & 412183 & 412183 & 412183 & 412183 \\
\hline \#Adoptive & 3941 & 3941 & 3941 & 3941 & 3941 \\
\hline
\end{tabular}

All (OLS-)estimations include a gender dummy for the child. Robust standard errors are given in brackets. The percentages between parentheses convert the estimates from percentage points to percentage as compared to the prevalence of entrepreneurship in the relevant sample of children and according to the relevant definition of entrepreneurship. Approx five percent of the entrepreneurial income data is missing. 


\begin{tabular}{|c|c|c|c|c|c|c|c|}
\hline & & \multicolumn{2}{|c|}{ Parent } & \multicolumn{2}{|c|}{ Father } & \multicolumn{2}{|c|}{ Mother } \\
\hline & & Bio & Adoptive & Bio & Adoptive & Bio & Adoptive \\
\hline & Adopted Children $(\mathrm{n}=3941$ & & & & & & \\
\hline (1) & $\begin{array}{l}\text { Baseline Results (from } \\
\text { Table 3) }\end{array}$ & $\begin{array}{l}0.037 * * \\
{[0.015]}\end{array}$ & $\begin{array}{c}0.084 * * * \\
{[0.014]}\end{array}$ & $\begin{array}{l}0.042 * * \\
{[0.017]}\end{array}$ & $\begin{array}{c}0.087 * * * \\
{[0.015]}\end{array}$ & $\begin{array}{c}0.034 \\
{[0.023]}\end{array}$ & $\begin{array}{c}0.093 * * * \\
{[0.019]}\end{array}$ \\
\hline (2) & $\begin{array}{l}\text { Test for Non-Random Assig } \\
\text { Exclude biological } \\
\text { parent entrepreneurship } \\
\text { and characteristics }\end{array}$ & nment & $\begin{array}{c}0.084 * * * \\
{[0.014]}\end{array}$ & & $\begin{array}{c}0.089 * * * \\
{[0.015]}\end{array}$ & & $\begin{array}{c}0.091 * * * \\
{[0.019]}\end{array}$ \\
\hline (3) & $\begin{array}{l}\text { Exclude adoptive parent } \\
\text { entrepreneurship and } \\
\text { characteristics }\end{array}$ & $\begin{array}{l}0.036^{* *} \\
{[0.015]}\end{array}$ & & $\begin{array}{l}0.041^{* *} \\
{[0.016]}\end{array}$ & & $\begin{array}{c}0.030 \\
{[0.023]}\end{array}$ & \\
\hline (4) & $\begin{array}{l}\text { Include biological parent } \\
\text { education and income }\end{array}$ & $\begin{array}{l}0.035 * * \\
{[0.015]}\end{array}$ & $\begin{array}{c}0.084 * * * \\
{[0.014]}\end{array}$ & $\begin{array}{l}0.040 * * \\
{[0.017]}\end{array}$ & $\begin{array}{c}0.088 * * * \\
{[0.015]}\end{array}$ & $\begin{array}{c}0.033 \\
{[0.023]}\end{array}$ & $\begin{array}{c}0.093 * * * \\
{[0.019]}\end{array}$ \\
\hline (5) & $\begin{array}{l}\text { Include adoptive parent } \\
\text { education and income }{ }^{\mathrm{a}}\end{array}$ & $\begin{array}{c}0.037 * * \\
{[0.015]}\end{array}$ & $\begin{array}{c}0.083 * * * \\
{[0.014]}\end{array}$ & $\begin{array}{l}0.041 * * \\
{[0.016]}\end{array}$ & $\begin{array}{c}0.089 * * * \\
{[0.015]}\end{array}$ & $\begin{array}{c}0.034 \\
{[0.023]}\end{array}$ & $\begin{array}{c}0.093 * * * \\
{[0.019]}\end{array}$ \\
\hline (6) & $\begin{array}{l}\text { Test for Non-linearities ( } n= \\
\text { Include interaction term } \\
\text { between biological and } \\
\text { adoptive parent }{ }^{\mathrm{b}} \\
\text { Missing Biological Fathers }\end{array}$ & $\begin{array}{l}3941) \\
0.045 * * \\
{[0.018]} \\
(n=8513)\end{array}$ & $\begin{array}{c}0.085^{* * *} \\
{[0.016]}\end{array}$ & $\begin{array}{l}0.036^{*} \\
{[0.019]}\end{array}$ & $\begin{array}{c}0.077 * * * \\
{[0.017]}\end{array}$ & $\begin{array}{c}0.034 \\
{[0.024]}\end{array}$ & $\begin{array}{c}0.088 * * * \\
{[0.020]}\end{array}$ \\
\hline (7) & $\begin{array}{l}\text { Include all with } \\
\text { identified biological } \\
\text { mothers } \\
\text { Own-Birth Children } \\
\text { Comparable Samples }\end{array}$ & & & & & $\begin{array}{c}0.037 * * \\
{[0.015]}\end{array}$ & $\begin{array}{c}0.095 * * * \\
{[0.013]}\end{array}$ \\
\hline (8) & $\begin{array}{l}\text { Baseline (columns (1) } \\
\text { and (3) of Table 3) } \\
\mathrm{N}=412183\end{array}$ & \multicolumn{2}{|c|}{$\begin{array}{c}0.116 * * * \\
{[0.001]}\end{array}$} & \multicolumn{2}{|c|}{$\begin{array}{c}0.088 * * * \\
{[0.002]}\end{array}$} & \multicolumn{2}{|c|}{$\begin{array}{c}0.089 * * * \\
{[0.002]}\end{array}$} \\
\hline (9) & $\begin{array}{l}\text { Positively Selected } \\
\text { Parents: Characteristics } \\
\text { match those of adoptive } \\
\text { parents }(n=3939)\end{array}$ & \multicolumn{2}{|c|}{$\begin{array}{c}0.102 * * * \\
{[0.014]}\end{array}$} & \multicolumn{2}{|c|}{$\begin{array}{c}0.086 * * * \\
{[0.016]}\end{array}$} & \multicolumn{2}{|c|}{$\begin{array}{c}0.078 * * * \\
{[0.020]}\end{array}$} \\
\hline (10) & $\begin{array}{l}\text { Negatively Selected } \\
\text { Parents: Characteristics } \\
\text { match those of biological } \\
\text { parents with adopted } \\
\text { away children }(\mathrm{n}=3742)\end{array}$ & \multicolumn{2}{|c|}{$\begin{array}{c}0.116 * * * \\
{[0.016]}\end{array}$} & \multicolumn{2}{|c|}{$\begin{array}{c}0.112 * * * \\
{[0.018]}\end{array}$} & \multicolumn{2}{|c|}{$\begin{array}{c}0.078 * * * \\
{[0.025]}\end{array}$} \\
\hline
\end{tabular}

${ }^{a}$ Education levels are included by using dummies for the number of years of education, where missing observations are included in a separate dummy variable. Missing values for parental income levels are set equal to their means. The results are similar when these observations are excluded.

${ }^{\mathrm{b}}$ The interaction terms are not tabulated. The estimates for these interaction terms are -0.011 [0.033], 0.039 [0.039], and 0.008 [0.075] for column 1 to 3, respectively. 
(1)

Baseline

(2)

Parental income

$\begin{array}{lr}\text { Nurture effect } & 0.089 * * * \\ \text { [s.e.] } & {[0.015]}\end{array}$

$\%$ decrease

adj $\mathrm{R}^{2}$

0.03

\section{$0.090 * * *$ \\ [0.015]}

$-1 \%$

0.03

Panel B: Adoptive Mothers
Panel A: Adoptive Fathers

\begin{tabular}{lccc} 
Nurture effect & $0.091 * * *$ & $0.091 * * *$ & $0.091 * * *$ \\
[s.e.] & {$[0.019]$} & {$[0.019]$} & $0.091 * * *$ \\
$\%$ decrease & & 0 & {$[0.017]$} \\
adj $\mathrm{R}^{2}$ & 0.03 & 0.03 & 0 \\
\hline \hline
\end{tabular}

$\begin{array}{cc}0.089 * * * & 0.080 * * * \\ {[0.014]} & {[0.019]} \\ 0 & 10 \% \\ 0.03 & 0.03\end{array}$

$10 \%$

.03
(4)

Parents industry

Parental wealth

OLS regressions. $\mathrm{N}=3,941$. Standard errors are robust; $* * *$ indicates significance at $1 \%$. All regressions include a gender, birth year, and county dummy for each child. They also include a birth year dummy for the parent in question. Column (2) includes the income of both adoptive parents. Column (3) includes a dummy variable equal to 1 if the parent is considered to be "wealthy". This is proxied by the fact that they are in the top decile of the distribution of pre-tax total factor income. This variable is included for both adoptive parents. Column (4) includes 42 two-digit SNI industry codes (plus a code for missing) for both adoptive parents for the years 1986, 1991, 1996, 2001 and 2006. 
Table 7. Nurture mechanism: Role-modeling. Baseline estimation for sons and daughters separately

\begin{tabular}{|c|c|c|c|c|c|c|c|c|}
\hline \multirow[b]{2}{*}{ Adopted children } & \multicolumn{2}{|c|}{ (1)* } & \multicolumn{2}{|c|}{$(2)^{*}$} & \multicolumn{2}{|c|}{ (3)* } & \multicolumn{2}{|c|}{ (4)* } \\
\hline & Girls & Boys & Girls & Boys & Girls & Boys & Girls & Boys \\
\hline \multicolumn{9}{|l|}{ Nurturing parents effect: } \\
\hline Father & 0.006 & $0.126 * * *$ & 0.009 & $0.125 * * *$ & 0.000 & $0.125 * * *$ & 0.003 & $0.126 * * *$ \\
\hline [s.e.] & {$[0.021]$} & {$[0.024]$} & {$[0.020]$} & {$[0.024]$} & {$[0.021]$} & {$[0.025]$} & {$[0.021]$} & {$[0.029]$} \\
\hline Mother & $0.065 * *$ & $0.055^{*}$ & $0.065 * *$ & $0.054 *$ & $0.069 * *$ & $0.062 * *$ & $0.064 * *$ & $0.056^{*}$ \\
\hline [s.e.] & {$[0.027]$} & {$[0.030]$} & {$[0.027]$} & {$[0.031]$} & {$[0.027]$} & {$[0.031]$} & {$[0.027]$} & {$[0.030]$} \\
\hline \# sister / \# brothers & & & & & & & $-0.010 *$ & -0.006 \\
\hline [s.e.] & & & & & & & {$[0.006]$} & {$[0.007]$} \\
\hline \# sister * Mother/ \# brothers * Father & & & & & & & -0.025 & $0.029 *$ \\
\hline [s.e.] & & & & & & & {$[0.018]$} & {$[0.016]$} \\
\hline F-test of difference (one-sided in expected direction) & $2.28 *$ & $2.42 *$ & $2.00 *$ & $2.35 *$ & $2.94 * *$ & $1.78^{*}$ & $3.48 * *$ & 0.72 \\
\hline $\mathrm{N}$ & 1792 & 2149 & 1792 & 2149 & 1792 & 2149 & 1792 & 2149 \\
\hline Own-birth children & Girls & Boys & Girls & Boys & Girls & Boys & Girls & Boys \\
\hline \multicolumn{9}{|l|}{ Nurturing parents effect: } \\
\hline Father & $0.042 * * *$ & $0.131 * * *$ & $0.044 * * *$ & $0.133 * * *$ & & & $0.042 * * *$ & $0.132 * * *$ \\
\hline [s.e.] & {$[0.002]$} & {$[0.002]$} & {$[0.002]$} & {$[0.002]$} & & & {$[0.002]$} & {$[0.002]$} \\
\hline Mother & $0.068 * * *$ & $0.108 * * *$ & $0.067 * * *$ & $0.108 * * *$ & & & $0.068 * * *$ & $0.108 * * *$ \\
\hline [s.e.] & {$[0.003]$} & {$[0.003]$} & {$[0.003]$} & {$[0.003]$} & & & {$[0.003]$} & {$[0.003]$} \\
\hline \# sister / \# brothers & & & & & & & -0.001 & $0.002 * * *$ \\
\hline [s.e.] & & & & & & & {$[0.001]$} & {$[0.001]$} \\
\hline \# sister $*$ Mother/ \# brothers * Father & & & & & & & $-0.006^{* * *}$ & $-0.011 * * *$ \\
\hline [s.e.] & & & & & & & {$[0.002]$} & {$[0.002]$} \\
\hline F-test of difference (one-sided in expected direction) & $46.28 * * *$ & $25.73 * * *$ & $33.89 * * *$ & $31.44 * * *$ & & & $49.14 * * *$ & $50.45 * * *$ \\
\hline $\mathrm{N}$ & 200964 & 211219 & 200964 & 211219 & & & 200964 & 211219 \\
\hline \multicolumn{9}{|l|}{ Controls included: } \\
\hline $\begin{array}{l}\text { Education \& occupation dummies and income of } \\
\text { nurturing parents** }\end{array}$ & \multicolumn{2}{|c|}{ NO } & \multicolumn{2}{|c|}{ YES } & \multicolumn{2}{|c|}{ YES } & \multicolumn{2}{|c|}{$\mathrm{NO}$} \\
\hline $\begin{array}{l}\text { Entrepreneur status and birth-year of non-nurturing } \\
\text { parents }\end{array}$ & \multicolumn{2}{|c|}{ NO } & \multicolumn{2}{|c|}{ NO } & \multicolumn{2}{|c|}{ YES } & \multicolumn{2}{|c|}{ NO } \\
\hline
\end{tabular}

*OLS regressions where the entrepreneurship status of both nurturing parents is included. Standard errors are robust. All regressions include birth year dummies and county of residence dummies in 1965 for the "boys"/"girls" as well as birth-year dummies for the nurturing parents. Column (2) includes the education and occupation dummies and income levels of both nurturing parents. Column (3) includes, in addition, the entrepreneurship status and birth-year dummies of the biological parents of adopted children. Column (4) includes the (mean-centered) number of sisters (brothers) in the girls (boys) regression, and an interaction of this variable with the mother's (father's) entrepreneurship status. ${ }^{* *}$ The equations estimated on the smaller adopted children samples of boys and girls in columns (2) and (3) do not include the occupation dummies in addition to the income controls and all birth year, county and education dummies. 
Appendix Table A1: Testing for Non-Random Assignment
(1)
(2)
(3)

\begin{tabular}{lccc}
\hline \multicolumn{3}{c}{ Dependent variable: Entrepreneur_adparent } \\
Entrepreneur_Bioparent & 0.008 & -0.006 & -0.003 \\
& {$[0.017]$} & {$[0.017]$} & {$[0.017]$} \\
\hline R-squared & 0.000 & 0.053 & 0.062 \\
$\begin{array}{l}\text { Year of birth and adoptive } \\
\text { parents dumies }\end{array}$ & NO & YES & YES \\
$\begin{array}{l}\text { Education dummies and } \\
\text { income controls for biological } \\
\text { and adoptive parents }\end{array}$ & NO & NO & YES \\
$\begin{array}{l}\text { Adoptive Observations } \\
\text { Ado }\end{array}$ & 3941 & 3941 & 3941
\end{tabular}

All (OLS-)estimations include a gender dummy for the child. Robust standard errors are given between brackets. 